\title{
Response of a low-subsiding intracratonic basin to long wavelength deformations: the Palaeocene-early Eocene period in the Paris Basin
}

\author{
J. Briais ${ }^{1,2}$, F. Guillocheau ${ }^{1}$, E. Lasseur ${ }^{2}$, C. Robin ${ }^{1}$, J. J. Châteauneuf ${ }^{3}$, and O. Serrano ${ }^{2}$ \\ ${ }^{1}$ Géosciences-Rennes, UMR6118, Université de Rennes 1 - CNRS, 35042 Rennes CEDEX, France \\ ${ }^{2}$ BRGM, 3 avenue Claude Guillemin, 45060 Orléans CEDEX, France \\ ${ }^{3}$ Biostratigraphy Consultant, 8 quai du Châtelet, 45000 Orléans, France
}

Correspondence to: J. Briais (j.briais@brgm.fr)

Received: 20 October 2015 - Published in Solid Earth Discuss.: 7 December 2015

Revised: 20 January 2016 - Accepted: 21 January 2016 - Published: 8 February 2016

\begin{abstract}
The uppermost Cretaceous to early Palaeogene is a period of major deformations of the western part of the Eurasian plate with prominent basin inversions starting from the Coniacian onwards. These deformations occur in a complex geodynamic setting within both the context of the Africa-Eurasia convergence and the North Atlantic opening. While Mesozoic graben inversions have been extensively studied, particularly in Eastern Europe and the North Sea, more gentle deformations that affect thicker crust areas (intracratonic basins and emerged lands) are not as well documented.

The objective of this study is to constrain the exact timing, type, and magnitude of the early Palaeogene deformations affecting the intracratonic Paris Basin and to integrate them at the western European scale. Low-amplitude deformations are attempted through a high-resolution reconstitution of its stratigraphic record based on well-dated outcrops and well-dated wells, and a high number of well-logs that are correlated using the "stacking pattern" sequence stratigraphic technique.
\end{abstract}

Two orders of sequences are identified (third and fourth order) and correlated throughout the basin. Basin geometric and palaeogeographic reconstitutions are based on sediment thickness and facies analysis. Two-dimensional accommodation space measurements were taken in order to quantify the magnitude of the deformations.

Three phases of deformation were recognized.

1. An intra-Maastrichtian-pre-Thanetian (59 Ma) deformation, with major uplift and erosion of the Cre- taceous strata with two sub-periods of deformation: Maastrichtian-pre-middle-Danian and Upper Danianpre-Thanetian long-wavelength deformations. This period of major deformation is coeval with Upper Cretaceous/pre-Danian compressive deformations linked to the Africa-Eurasia convergence in southern France and with volcanic activity from the North Atlantic to Massif Central and the Rhenish Shield during the Palaeocene.

2. An early Ypresian (55.1-54.3 Ma) medium-wavelength deformation $(\times 10 \mathrm{~km})$, here reported to be a stress rearrangement related to the onset of the North Atlantic opening.

3. An uppermost Ypresian (49.8 Ma) long-wavelength deformation $(\times 100 \mathrm{~km})$, contemporaneous with flexural compressive deformations in the Aquitaine Basin (Pyrenean deformation), and related to the Iberia-Eurasia convergence.

\section{Introduction}

The Paris Basin is one of the most documented basins in the world. It has been studied since the 18th century (Guettard, 1746) and is considered as a typical example of intracratonic basins (Pomerol, 1989; Brunet and Le Pichon, 1982; Perrodon and Zabek, 1990). Subsidence and accommodation space measurements (Brunet and Le Pichon, 1982; Guil- 
locheau et al., 2000) have shown that the Paris Basin was a subsiding domain until the Cretaceous-Palaeogene boundary and an uplifted emerged area related to Alpine collision since the end of the Rupelian. In between, Cenozoic deposits were deposited in a very low accommodation regime (5-15 $\mathrm{m} \mathrm{Ma}^{-1}$ ), separated by large time hiatuses (Pomerol, 1989). Deformation phases of the Eurasian plate have been documented from the end of the Cretaceous to the Oligocene and are tentatively related to various phases of convergence (Ziegler, 1990, 1992) or to the Atlantic opening (Anell et al., 2009 and Doré et al., 1999). These phases vary from graben inversions in the North Sea (Ziegler, 1987a), British Isles (Isle of Wight, St George's Channel, Western Approaches; Ziegler, 1987b), Germany, and Polish Trough to more gentle flexures affecting former sag basins (Cloetingh and Van Wees, 2005). The characteristics and mechanisms of the prominent inversion of Mesozoic grabens have been extensively studied (Ziegler, 1990; Doré et al., 1999; Lamarche et al., 2003; Anell et al., 2009); conversely, the subtle deformations of thicker crust basins such as the Paris Basin and their relationship to far-field stresses are less well known.

The Palaeocene to early Eocene evolution of the Paris Basin is documented here through a detailed stratigraphical and sedimentological study (Briais, 2015).

The 3-D geometry of the late Palaeocene to early Eocene sediments of the Paris Basin is reconstructed based on sequence stratigraphic correlations of the wells (with well$\operatorname{logs}$ ), calibrated in age, and facies on stratigraphic wells, available in the literature and outcrops. An absolute age model of the main surfaces is compiled based on the biostratigraphy, sequence stratigraphic surfaces, high-resolution oxygen isotope curves (Cramer et al., 2011), and Earth orbital solutions for long-term eccentricity (Laskar et al., 2011). A 2-D accommodation space measurement was taken to quantify the magnitude of the deformations.

The timing and type of deformation are tentatively correlated to the main geodynamic events that affected the European plate during the early Cenozoic.

\section{Geological setting}

\subsection{Crustal structure (Fig. 1)}

The lithosphere of the Paris Basin is inherited from the Variscan mountain belt resulting from the carboniferous collision of the Avalonia and Gondwana plates and the closure of the RHEIC Ocean (Matte, 1986). The suture of this ocean corresponds to the Bray-Metz Fault (Autran et al., 1994; see Fig. 1a). Recent studies based on the $P$ wave seismic tomography (Averbuch and Piromallo, 2012) have suggested the occurrence of a subducted slab beneath a part of the Bray Fault (Fig. 1b). On the Gondwana side, the pattern is much more complex with a major fault system, the Seine Fault, corresponding to a magnetic anomaly, the AMBP (Magnetic anomaly of the Paris Basin); the origin of which is controversial (Palaeozoic rift: Autran et al., 1986; fossil slab: Averbuch and Piromallo, 2012).

The Seine, Rambouillet, and Loire faults represent the eastern limit of the Cadomian (para-autochthonous block) and the Hurepoix Block, bounded by the Seine, Valpuiseaux, and Rambouillet faults, forms a distinct block as evidenced by geophysics (Autran et al., 1994).

After the collision, the mountain belt collapsed with the growth of numerous Permian basins located along the major faults; the exact location of these basins is unknown (Mégnien and Mégnien, 1980; Mascle, 1990; Perrodon and Zabeck, 1990; Delmas et al., 2002).

\subsection{Deformation history}

The subsidence of the Paris Basin started during early Triassic times. The long-term subsidence pattern is subdivided into three parts: (1) Trias-Cretaceous, a subsiding domain with a mean subsidence rate close to $20 \mathrm{~m} \mathrm{Ma}^{-1}$; the subsidence is usually considered as of thermal origin due to the Permo-Trias extension (Perrodon and Zabeck, 1990), (2) Palaeocene-early Oligocene, with low subsidence close to $10 \mathrm{~m} \mathrm{Ma}^{-1}$, and (3) uplift since the late Oligocene (Guillocheau et al., 2000). These changes record a major plate reorganization during the uppermost Cretaceous-early Palaeocene and late Oligocene-early Miocene events. During its subsidence history, the Paris Basin also records intraplate deformations; the most spectacular one occurred in early Cretaceous times during the opening of the Bay of Biscay and the rotation of Iberia (Neo-Cimmerian and Austrian deformations; Ziegler, 1990). This deformation is recorded by an uplift of the basin borders and by a NW-SE-orientated flexure within the basin (Guillocheau et al., 2000).

Palaeocene and Eocene deformations are recorded in the Paris Basin by emersions, erosions, and hiatuses (early Danian, Selandian, and Upper Ypresian; Pomerol, 1989), but the sedimentary geometries and amplitude of these vertical movements are not well characterized. Uppermost Cretaceous-early Palaeocene is thought to be a period of important intraplate deformations (Guillocheau et al., 2000) and of major vertical movements (Barbarand et al., 2013).

Several faults are active during this evolution: (1) inherited Variscan faults such as the Bray-Vittel Fault or (2) newly formed faults. The most efficient faults are the ones bounding the different Variscan units of the continental crust (Beccaletto et al., 2011).

\subsection{Sedimentary infilling}

The sedimentary record of the Mesozoic period is controlled by tectonically induced second-order transgressiveregressive cycles bounded by unconformities corresponding to the intraplate deformation events mentioned above (Guillocheau, 1991; Guillocheau et al., 2000). The sediments 


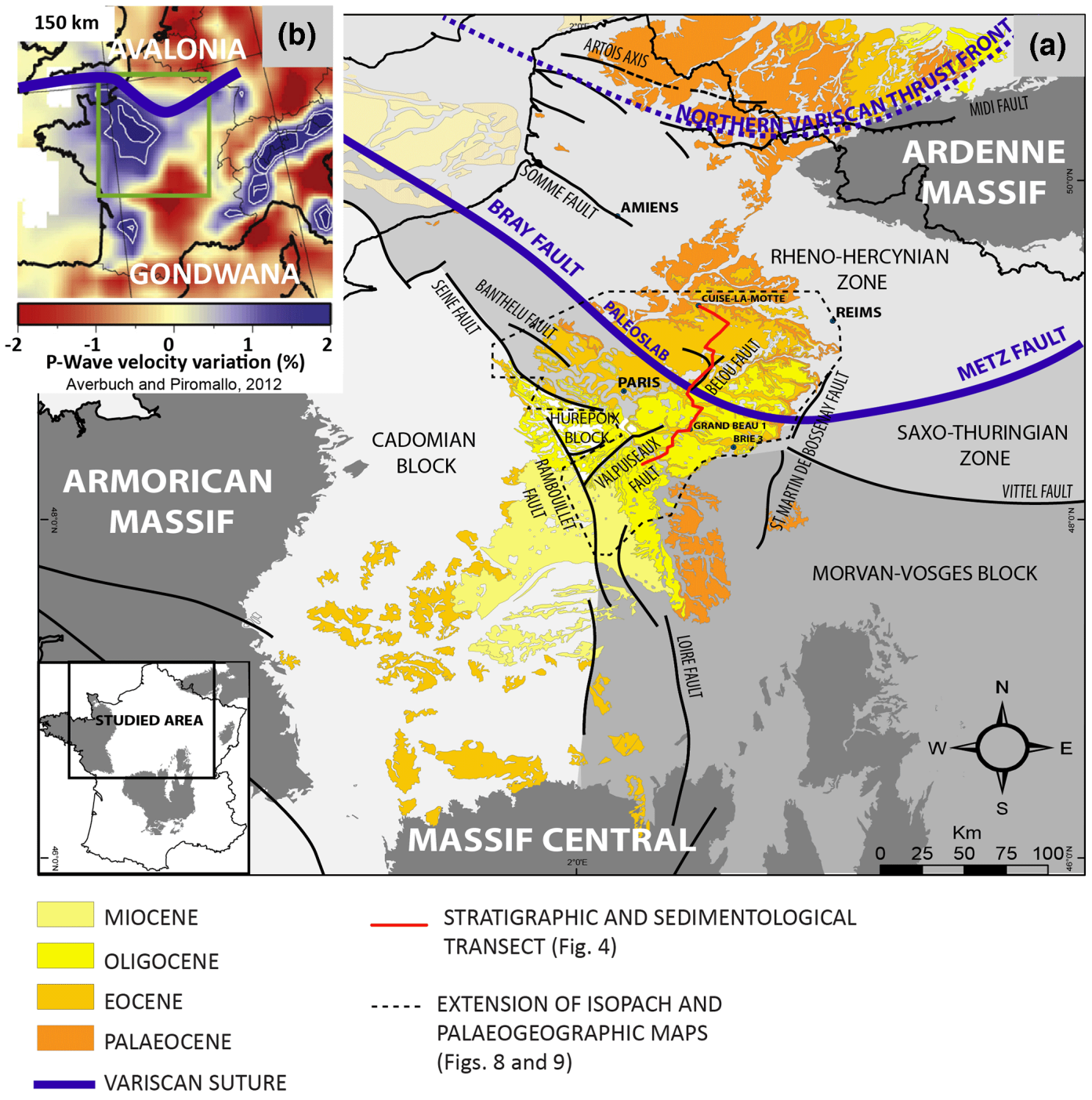

Figure 1. Geological characteristics of the Paris Basin. (a) Main tectonic units of the Variscan basement and present-day outcrops of the Cenozoic sediments. (b) $P$ wave velocity at $150 \mathrm{~km}$ below the Paris Basin, showing a major discontinuity below the Bray Fault (blue line), one of the sutures of the Variscan Belt (from Averbuch and Piromallo, 2012).

are mainly siliciclastic during Triassic and early Cretaceous times and carbonate marl during Jurassic and late Cretaceous (chalk) times.

The Cretaceous-Palaeogene transition is made up of three main stratigraphic units bounded by two hiatuses: (1) the Upper Cretaceous chalk, (2) the mid-to-late Danian limestones, and (3) the Thanetian sands (Lemoine, 1911).

The low-subsiding Palaeogene period is subdivided into two units bounded by a major discontinuity during the late Ypresian. The first group (Thanetian-Ypresian) is the subject of this study and is composed of siliciclastic deposition. The second one is composed of carbonates (Lutetian), siliciclastic sediments (early Bartonian), carbonates and evaporites (late Bartonian to early Rupelian), followed again by siliciclastic sediments (Rupelian). The major marine flood- ings are late Thanetian, early Lutetian, early Bartonian, and early Rupelian in age (Guillocheau et al., 2000).

\section{Methods}

This study is based on the correlation of wells (well-logs with a description of the cuttings and a few cores) and outcrops (Fig. S1 in the Supplement).

The well-log database consists of: (1) 213 petroleum wells (gamma-ray and few resistivity logs), (2) 50 petroleum coredrills (spontaneous polarization and resistivity), and (3) 114 seismic core-drills (gamma-ray only). Data (1) are available from BEPH ("Bureau Exploration Production des Hydrocarbures", www.beph.net), (2) and (3) are available in the BSS ("Banque du Sous-Sol", http://infoterre.brgm.fr). 
The few cores that are available come from scientific programmes of the 1960s and 1970s (Chaignes, Montjavoult, Le Ludes, Cuise-la-Motte, Le Tillet, Mont Bernon; Paris University/BRGM projects), mining projects (Provins, Brie 1, 2, 3, 4; Wyns and Ducreux, 1983), or BEPH fundings (Ste Colombe, "Craie 700" project; Mégnien and Hanot, 2000; Fig. S1).

Few outcrops are available. Most of them are quarries in operation.

\subsection{Sequence stratigraphy: well-log correlations and cycle definitions}

Here, we define transgressive-regressive stratigraphic cycles (Guillocheau, 1991) based on the evolution of the sedimentary environments and their stacking pattern. Three types of surfaces are defined: (1) maximum flooding surfaces (MFS - Galloway, 1989; Catuneanu et al., 2009, corresponding in open marine environments to the deepest or most distal surface along a depositional profile), (2) maximum regressive surfaces (MRS - Catuneanu et al., 2009, corresponding in open marine environments to the shallowest or the most proximal surface along a depositional profile), and (3) unconformities (UN - Embry, 2009, corresponding to an erosion surface in continental environments or to a downward shift of the shoreline).

The 3-D reconstruction of the sedimentary geometries by well correlations at the basin scale (stacking pattern method for the shortest duration stratigraphic cycles; Van Wagoner et al., 1988, 1990; Homewood et al., 1992) is a six-step procedure.

1. Definition of sedimentary environments on outcrops and cores, using the classical technique of sedimentary facies analysis: successive depositional profiles were defined for time intervals bounded by major palaeogeographic reorganizations.

2. Calibration of well-logs in terms of sedimentary environments: from areas where outcrops are close to the wells (less than $1 \mathrm{~km}$ ), a characteristic well-log pattern (values and shape) was defined and so that the signature of the well-logs for the different depositional environments could be identified (Fig. S5).

3. Definition of the different orders of cycles on the reference boreholes: according to their duration provided by the age model, two orders were defined: third order between 1 and $5 \mathrm{Ma}$ (Haq et al., 1987) and fourth order for 400 and 800 Kyrs cycles imbricated within third order.

4. Correlation of the different orders of cycles from well to well.

5. Test of the sequence stratigraphic framework and the hierarchy cycles by their 3-D geometry.
6. Validation and definitive dating (see below) of the different orders of cycles.

Palaeographic maps at the level of the main surface (MFS) are then compiled from the various recognized sedimentary environments. Isopach maps between the major surfaces are produced from the interpolation thickness (compacted) in the wells using the kriging method with a geographic information system (ArcGis and Gocad).

\subsection{Sequence stratigraphy: accommodation space measurement}

The accommodation space available for sediments is the sum of the tectonic and eustatic variations (Jervey, 1988; Schlager, 1993). It can be measured (Robin et al., 1998), for a given time interval, as the decompacted thickness of the deposited sediments, corrected from the palaeobathymetries/palaeoaltitudes at which the sediments were deposited. This requires (1) high-resolution time lines, across the basin, referred to in absolute ages, (2) lithological and porosity data, and (3) an estimation of the palaeodepths or palaeoelevations.

\section{Time lines calibrated in absolute ages}

In a low-subsidence setting, the time resolution of the dating is of primary importance to quantify the accommodation at high resolution. Palaeogene deposits are dated by biostratigraphy and chemostratigraphy, but only the PETM (Palaeocene-Eocene Thermal Maximum) is dated by chemostratigraphy (Quesnel et al., 2011). Biostratigraphic data are based on calcareous nannofossils (Aubry, 1983; Janin and Bignot, 1993; Bignot et al., 1994; Steurbaut, 1998), dinocysts (Wezellielacea - Chateauneuf and GruasCavagnetto, 1978), benthic foraminifera (Bignot and Neumann, 1991), charophytes (Pomerol and Riveline, 1975), and mammals (Russel, 1964; Nel et al., 1999; Smith et al., 2014). Dinocyst data were re-evaluated within the framework of this study by one of us (J. J. Chateauneuf - see Fig. S3).

Unfortunately, as most of the sedimentary record consists of continental to shallow marine deposits, the biostratigraphic record is quite discontinuous (except for the dinocysts) with marine markers (foraminifera and calcareous nannofossils) only preserved in transgressive peaks (MFS). The second limit for the precision of the biostratigraphy is the discrepancy between the reference marine biozone and the other ones (dinocysts); large variations occur in the different charts available, e.g. Gradstein et al. (2012) and Köthe (2003, 2012). Dinocysts and wetzieliellaceae biostratigraphic-scale resolution is around $1 \mathrm{My}$, thus using both scales together implies that resolution can be considered as below $1 \mathrm{My}$.

As already mentioned, time lines are the sequence stratigraphy time lines defined above (mainly MRS and MFS). Some unconformities (UN) are also used. Our age model is based on a combination of biostratigraphy, chemostratigrahy, 
and cyclostratigraphy. In a given biozone, defined by biostratigraphy, the absolute age of MRS, MFS, and UN is fixed using inverted oxygen isotope curves (Cramer et al., 2009) recalibrated on the ICS12 chart by Gradstein et al. (2012) and the most recent orbital solutions provided by Laskar et al. (2011) as proxies for sea level variations.

Within the range of the different biozones, a maximum flooding surface (deepest facies) has to be a warm peak (chemostratigraphy) which corresponds to a proxy of decrease of the ice volume and an increase of the sea level (Cramer et al., 2011); a maximum flooding has to be a higheccentricity period (orbital solutions); the reverse is found for the maximum regressive surface.

\section{Estimation of decompacted thicknesses from lithology and porosity data}

Lithologies were determined from well-logs, cuttings, cores, and outcrops. Decompaction of the sediments was based on: (1) the sediment porosity at the time of their deposition, and (2) the porosity-depth coefficient, both of which are directly linked to the unit lithology. Here, we use a new compilation of compaction laws (Dabrio, 1982). This compilation takes envelope surfaces into account, including the global range of porosity versus depth for four main lithologies (sandstone, clay, carbonate, and silt). Here, we only use three lithologies: (1) sand, (2) carbonate, and (3) clay. These envelopes can be used to define the upper and lower compaction curves that are used to calibrate the error induced by the compaction law. Late erosion of the deposits overlying the Palaeogene sediments can be considered as relatively low, thus the current depth can be used as an approximation of the maximum burial depth of the studied deposits.

\section{Palaeodepth/palaeoelevation measurement}

Palaeodepth/palaeoelevation measurements are based on the type of sedimentary environments defined both on (1) outcrops, cuttings, and cores, and (2) their well-log signatures (Fig. S5). The palaeodepth is deduced from the location of the facies compared to the fair-weather wave base $(-5$ to $-30 \mathrm{~m}$, Howard and Reineck, 1981). By comparison with present-day environments, coastal plain environments are assumed to be few metres above mean sea level. The palaeoelevation is estimated defining topographic trends deduced from the palaeogeography during earlier stages of deposition.

In the case of erosion, eroded thicknesses are estimated using extrapolation of preserved thicknesses in parts of the basin and considering a coherent trend of thickness variations using of underlying series. Eroded thicknesses are estimated from internal sedimentary geometries.

\section{Error calculation}

Different tests were performed in order to quantify the uncertainties on the accommodation values.
1. High-resolution time lines: possible miscorrelations were minimized by multiple inter-well correlations (Fig. S1); isopachs do not show any error.

2. Decompacted lithologies: in most of the correlated well logs, only gamma rays were measured. Estimations of the lithologies are based on descriptions of the well cuttings and the proportion of clay is estimated from the gamma-ray measurement; possible errors are reduced by tests on the various compaction laws.

3. Palaeodepth/palaeoelevation: several scenarios were tested and are presented in Sect. 4.3.

\section{Results and interpretation}

\subsection{Depositional model}

Ten sedimentary facies associations are identified here (see Table 1 and the images in Fig. S4). They are characteristic of shallow marine, large embayment (protected marine), coastal plain (marshes), and continental (lake and channel rivers) environments.

\section{Wave-dominated coastal deposits}

FA1 and FA2 are characterized by homolithic well-sorted siliciclastic sands with HCS (Hummock Cross Stratification), SCS (Swaley Cross Stratification), and numerous recurrent scours (furrows). These sedimentary structures are encountered in wave-dominated coastal environments (shoreface to inner storm ramp; Greenwood and Sherman, 1986; Hampson and Storms, 2003) deposited above the fair-weather wave base (Harms, 1975; Leckie and Walker, 1982; Walker and Plint 1992; Reading and Collinson, 1996; FA1).

Some beach deposits exist (FA2), made up of coarsegrained sands with low-angle cross-bedding (Harms, 1975) overlying concave-up 2-D and 3-D megaripples, characteristic of ridges and runnels (Clifton et al., 1971; Davis et al., 1972; Hunter et al., 1979; Dabrio, 1982) at the transition between the foreshore and shoreface.

\section{Flood-dominated coastal deposits}

FA3 are characterized by compound cross-bedding (Harms, 1975), migrating toward the open sea. These compound bedsets, with graded oblique laminasets, acyclic clay deposits between the laminasets, and a unidirectional palaeocurrent (Wright, 1977; Postma, 1990) pattern (no tidal deposit criteria such as reverse current or tidal bundles), are characteristic of mouth bars (Elliot, 1986).

\section{Tide-dominated coastal deposits}

FA4, 5, and 6 contain classical sigmoidal cross-bedding (Allen, 1980), characteristic of tidal deposits (Allen, 1980, 
Table 1. Facies description and interpretation.

\begin{tabular}{|c|c|c|c|c|c|}
\hline $\begin{array}{l}\text { Facies Asso- } \\
\text { ciation }\end{array}$ & Lithology and content & Structures & Bioturbation & Fossils & Process and Interpretation \\
\hline FA1 & $\begin{array}{l}\text {-Medium-grained sands } \\
\text {-Well-sorted sands } \\
\text {-Some bioclastic layers mainly com- } \\
\text { posed of } \\
\text { gastropods and bivalves }\end{array}$ & $\begin{array}{l}\text {-HCS (Harms, 1975) and SCS (Leckie } \\
\text { and Walker, 1982) with furrows } \\
\text {-Bioclastic concentrations (poly- } \\
\text { typic, concordant biofabric, bioclast- } \\
\text { supported, stringer geometry, and } \\
\text { simple internal structure; Kidwell } \\
\text { et al., 1986) at the base of SCS and } \\
\text { within }\end{array}$ & Absent & $\begin{array}{l}\text { Gastropods and } \\
\text { bivalves }\end{array}$ & $\begin{array}{l}\text {-Oscillatory (Arnott and Southard, 1990; } \\
\text { Dumas et al., 2005) } \\
\text {-Storm dominated (Leckie and Walker, } \\
\text { 1982; Greenwood and Sherman, 1986) } \\
\text {-Shoreface (Hampson and Storms, 2003) }\end{array}$ \\
\hline FA2 & $\begin{array}{l}\text {-Medium-grained sands } \\
\text {-Well-sorted sands } \\
\text {-Bioclastic sands } \\
\text {-Rare rounded pebbles (flint and } \\
\text { quartz) } \\
\text {-Heavy minerals }\end{array}$ & $\begin{array}{l}\text {-Low-angle cross-bedding (Harms, } \\
\text { 1975) } \\
\text {-Low-preservation current megarip- } \\
\text { ples } \\
\text {-Concave-up 2-D-3-D } \\
\text {-Asymmetric ripples of varying angle } \\
\text { (with pebbles lenses at the base) = } \\
\text { ridges and runnels (Clifton et al., 1971; } \\
\text { Davis et al., 1972; Hunter et al., 1979; } \\
\text { Dabrio, 1982) } \\
\text {-Bioclastic concentrations (poly- } \\
\text { typic, concordant biofrabric, matrix- } \\
\text { supported, stringer geometry and } \\
\text { simple internal structure; Kidwell et } \\
\text { al., 1986) }\end{array}$ & $\begin{array}{l}\text { Root traces } \\
\text { on the top }\end{array}$ & $\begin{array}{l}\text { Gastropods and } \\
\text { bivalves highly } \\
\text { fractured }\end{array}$ & $\begin{array}{l}\text {-Breaking and surfing wave zone with tidal } \\
\text { influences (Clifton et al., 1971; Davis et al., } \\
\text { 1972; Dabrio, 1982) } \\
\text {-Foreshore and upper shoreface }\end{array}$ \\
\hline FA3 & $\begin{array}{l}\text {-Medium to coarse-grained sands } \\
\text { (finning-up) } \\
\text {-Poorly sorted sands } \\
\text {-Clay layer intercalations } \\
\text {-Few rounded pebbles (mud clast, } \\
\text { flint, and quartz) }\end{array}$ & $\begin{array}{l}\text {-Oblique laminaset with avalanching } \\
\text { (laminaset thickness }>1 \mathrm{~m} \text { ) } \\
\text {-Acyclic clay draping } \\
\text {-Compound cross-bedding }\end{array}$ & Moderate & & $\begin{array}{l}\text {-Unidirectional flow (Wright, 1977; Postma, } \\
\text { 1990) } \\
\text {-Flood dominated } \\
\text {-Mouth bar (Elliot, 1986) }\end{array}$ \\
\hline FA4 & $\begin{array}{l}\text {-Medium to coarse-grained sands } \\
\text {-Poorly sorted sands } \\
\text {-Mud drapes } \\
\text {-Rounded pebbles mud clasts }\end{array}$ & $\begin{array}{l}\text {-Sigmoïdal cross-bedding with tidal } \\
\text { bundles bounded by mud couplets } \\
\text { drapes (Mutti et al., 1985) } \\
\text {-Compound cross-bedding } \\
\text {-Rare asymmetric current ripple cross- } \\
\text { lamination recorded between mud } \\
\text { drapes }\end{array}$ & $\begin{array}{l}\text { Moderate } \\
\text { (vertical bur- } \\
\text { rows: } \\
\text { Ophiomorpha) }\end{array}$ & & $\begin{array}{l}\text {-Bidirectional flow (tide; Visser, 1980; } \\
\text { Allen, 1980; Nio and Yang, 1991) } \\
\text {-Subtidal bar (Allen, 1980) } \\
\text {-Outer estuarine (Dalrymple and Choi, } \\
\text { 2007) }\end{array}$ \\
\hline FA5 & $\begin{array}{l}\text {-Alternations of clays and fine to } \\
\text { medium-grained sands } \\
\text {-Poorly sorted sands }\end{array}$ & $\begin{array}{l}\text {-Lenticular or wavy bedding } \\
\text { (Reineck and Wunderlich, 1968) } \\
\text {-Asymmetric current ripples } \\
\text {-Recurrent double mud drapes }\end{array}$ & Intensive & & $\begin{array}{l}\text {-Tides (as above) } \\
\text {-Inner estuarine: tidal flat (Dalrymple and } \\
\text { Choi, 2007) }\end{array}$ \\
\hline FA6 & $\begin{array}{l}\text {-Alternations of clays and fine-grained } \\
\text { sands } \\
\text {-Poorly sorted sands } \\
\text {-Clay dominated }\end{array}$ & $\begin{array}{l}\text {-Rare lenticular bedding (Reineck and } \\
\text { Wunderlich, 1968) } \\
\text {-Few asymmetric ripples }\end{array}$ & $\begin{array}{l}\text { Intensive } \\
\text { Roots (hydromor- } \\
\text { phic) }\end{array}$ & & $\begin{array}{l}\text {-Tides (as above) } \\
\text {-Inner estuarine: supratidal (Dalrymple and } \\
\text { Choi, 2007) }\end{array}$ \\
\hline FA7 & $\begin{array}{l}\text { a -Fine to medium-grained sands } \\
\text {-Abundant bioturbation with shell ac- } \\
\text { cumulation } \\
\text { with low diversity fauna } \\
\text { b } \\
\text {-Fine to medium-grained sands } \\
\text {-Abundant bioturbation with shell ac- } \\
\text { cumulation } \\
\text { with low-diversity fauna } \\
\text { c } \\
\text {-Fine to medium-grained sands } \\
\text {-Glauconic (autochthonous, Amorosi, } \\
\text { 1997) bioturbated sands } \\
\text {-No shell, but oligospecific trace fos- } \\
\text { sils }\end{array}$ & $\begin{array}{l}\text {-Bioclastic concentrations (mono- } \\
\text { typic, } \\
\text { concordant biofrabric, bioclast- } \\
\text { supported, stringer geometry, and } \\
\text { simple internal structure; Kidwell et } \\
\text { al., 1986) } \\
\text {-Bioclastic concentrations (polytypic, } \\
\text { concordant biofrabric, matrix- } \\
\text { supported, stringer geometry, and } \\
\text { simple internal structure; Kidwell et } \\
\text { al., 1986) }\end{array}$ & $\begin{array}{l}\text { Intensive } \\
\text { (vertical bur- } \\
\text { rows) } \\
\text { Intensive } \\
\text { (vertical bur- } \\
\text { rows) } \\
\text { Intensive } \\
\text { (vertical burrows) }\end{array}$ & $\begin{array}{l}\text { Nummulites } \\
\text { Gastropods and } \\
\text { bivalves }\end{array}$ & $\begin{array}{l}\text {-Probably occasional storms (Kidwell et al., } \\
\text { 1986) } \\
\text {-Protected marine } \\
\text {-Protected marine } \\
\text {-Protected marine }\end{array}$ \\
\hline FA8 & $\begin{array}{l}\text { a -Alternations of clays with some } \\
\text { bioclastic (mainly molluscs) layers and } \\
\text { sands } \\
\text { b } \\
\text {-Alternations of organic matter-rich } \\
\text { clays and lignites }\end{array}$ & & & $\begin{array}{l}\text { Fresh and brackish water fau- } \\
\text { nas: } \\
\text { molluscs, } \\
\text { ostracods, } \\
\text { pollens, } \\
\text { few charophytes }\end{array}$ & $\begin{array}{l}\text {-Decantation } \\
\text {-Coastal plain: lagoon (Feugueur, 1963; } \\
\text { Chateauneuf and Gruas-Cavagnetto, 1978) } \\
\text {-Coastal plain: marshes with small lakes } \\
\text { (Gruas-Cavagnetto, 1976) }\end{array}$ \\
\hline FA9 & $\begin{array}{l}\text {-Medium to coarse-grained sands and } \\
\text { clays } \\
\text {-Clays dominated } \\
\text {-Rich in organic matter } \\
\text {-Poorly sorted sands }\end{array}$ & $\begin{array}{l}\text {-Lenticular sandbodies interdigited } \\
\text { into organic matter-rich clays } \\
\text {-Channel shape with erosive base and } \\
\text { finning-up trend; 2-D-3-D megaripple } \\
\text { with some compound cross-bedding } \\
\text { stratifications. }\end{array}$ & Root traces & & $\begin{array}{l}\text {-Unidirectional flow } \\
\text {-Alluvial plain with channels (low sinuosity; } \\
\text { Wyns and Ducreux,1983; Thiry, 1989) }\end{array}$ \\
\hline FA10 & $\begin{array}{l}\text {-Fine-grained limestone (mudstone) or } \\
\text { marls }\end{array}$ & Structureless & Root traces & $\begin{array}{l}\text { Fresh water oysters and } \\
\text { charophytes }\end{array}$ & $\begin{array}{l}\text {-Carbonate precipitation } \\
\text {-Lake (Dutheil et al., 2002) }\end{array}$ \\
\hline
\end{tabular}


1982; Allen and Homewood, 1984; Visser, 1980; Nio and Yang, 1991; Dalrymple and Choi, 2007). Three different types of tidal environments were recognized: (1) subaqueous tidal bars (outer estuary or bay - FA4) characterized by compound cross-bedding with sigmoidal cross-bedding and tidal bundles (Allen, 1980), (2) tidal flats with small-scale current lamination and mud drapes (FA5), and (3) supratidal claydominated deposits with few asymmetric ripples (sands) and some roots occurrences (FA6).

\section{Protected marine environments}

Large embayments (FA7) are characterized by extremely bioturbated glauconitic sands with poorly preserved sedimentary structures. Wave deposits are missing, thereby suggesting a large embayment protected from the wave energy. This interpretation is supported by a quite low shell biodiversity (oligospecific), indicating a stressed environment (e.g. salinity decrease or/and depleted oxygenation). The three different facies sub-associations (FA7a to c) record different degrees of confinement, from the outer (FA7a) to inner (FA7c) bays. FA7a shows no evidence of wave activity but a normal shell biodiversity, whereas FA7c shows also no wave activity, but no shells or oligo- (to mono-) specific trace fossils.

\section{Coastal plain environments}

FA8 are characterized by clays, sands and lignites with (1) brackish (e.g. Cyrena cuneiformis) to (2) fresh water (Viviparus suessoniensis) faunas (Feugueur, 1963; Chateauneuf and Gruas-Cavagnetto, 1978). Brackish clays and sands are more characteristic of lagoon deposits (FA8a) while fresh water organic-rich clays and lignites with intercalated soils (mangroves: Gruas-Cavagnetto, 1976) are more characteristic of marshes with small lakes (FA8b).

\section{Alluvial plain environments}

FA9 are characterized by (1) silty clays with root traces and no evidence of marine to brackish shells and trace fossils interpreted as floodplain, and (2) lenticular sand bodies interdigited into organic matter-rich clays interpreted as fluvial channels (Wyns and Ducreux, 1983; Thiry, 1989).

\section{Lacustrine environments}

FA10 are characterized by more or less clayey fine-grained limestones (mudstones texture) with charophytes and fresh water oysters and gastropods (Feugueur, 1963; Pomerol et al., 1977; Wyns and Ducreux, 1983; Riveline, 1984; Dutheil et al., 2002). Some calcretes at the top of lacustrine limestones and karst were described (Thiry, 1981; Aubry et al., 2005).

\subsection{Depositional cycle and facies distribution along a S-N transect (Melun-Soissons): definition of the stratigraphic cycles and isopach units}

The existing Cenozoic lithostratigraphic nomenclature of the Paris Basin is quite complex and confusing, resulting from roughly two centuries of geological studies in a low subsiding basin with numerous facies variations through time and space at the marine-continental domain transition. Aubry et al. (2005) have proposed a simplified lithostratigraphy with the creation of new formations (Fig. 2). This new lithostratigraphy is defined on the border (onlapping parts) of the subsiding domain and involves unfortunately large lacunae. In the present work, we define a homogenized lithostratigraphy that takes both the basin and border sedimentary packages into account based on our correlations (Figs. 2, S2, and 4).

A S-N transect extending from Melun to Soissons (Cuisela-Motte) summarizes the main geometrical features of the Palaeocene-early Eocene period in the Paris Basin (Figs. 4 and S6). It is based on the correlations of 31 wells using the stacking pattern technique (Sect. 3.1). The stratigraphy of the wells at each extremity of the section (the most marine one to the north, Sailly 1, and a more continental one to the south, Grand Beau 1) was defined and dated by correlation with two stratigraphic wells (Cuise-la-Motte and Brie 3; see Figs. 2 and S2). The well-logs facies used and their interpretation are summarized in Fig. S5.

The Thanetian third-order cycle (Ct, surfaces T1 to T4) is characterized by sediments onlapping southward over the late Campanian chalk. The uppermost Cretaceous (Upper Campanian and Maastrichtian), Danian, and Selandian are missing here (hiatus of $17 \mathrm{Ma}$ between 76 and $59 \mathrm{Ma}$; Pomerol, 1989).

The bounding surfaces of the cycle are defined as follows (Fig. 2):

- Base MRS (T1): base of the "Tuffeau de Moulin Compensé" Fm (shallow marine glauconitic calcareous sands), probably dated NP7 (Steurbaut, 1998; see discussion below).

- MFS (T2): top of the "Tuffeau de Moulin Compensé" Fm (nannofossil-rich top layer, Janin and Bignot, 1993 - FA1); the age is debated: NP6 for Janin and Bignot (1993) and NP7 for Steurbaut (1998). We prefer to use the work of Steurbaut, because it is more integrated at European scale.

- Unconformity: a sharp transition between the wavedominated shore deposits (FA1) of the Bracheux Sands Fm (HST) and the fluvio-estuarine (tidal dominated, Dutheil et al., 2002 - FA3 to FA5) Bourguillemont Sands Fm dated by Steurbaut (1998) around the NP8NP9 transition. This unconformity is the time equivalent of the Cernay conglomerate Fm (Laurain and Meyer, 1986). 


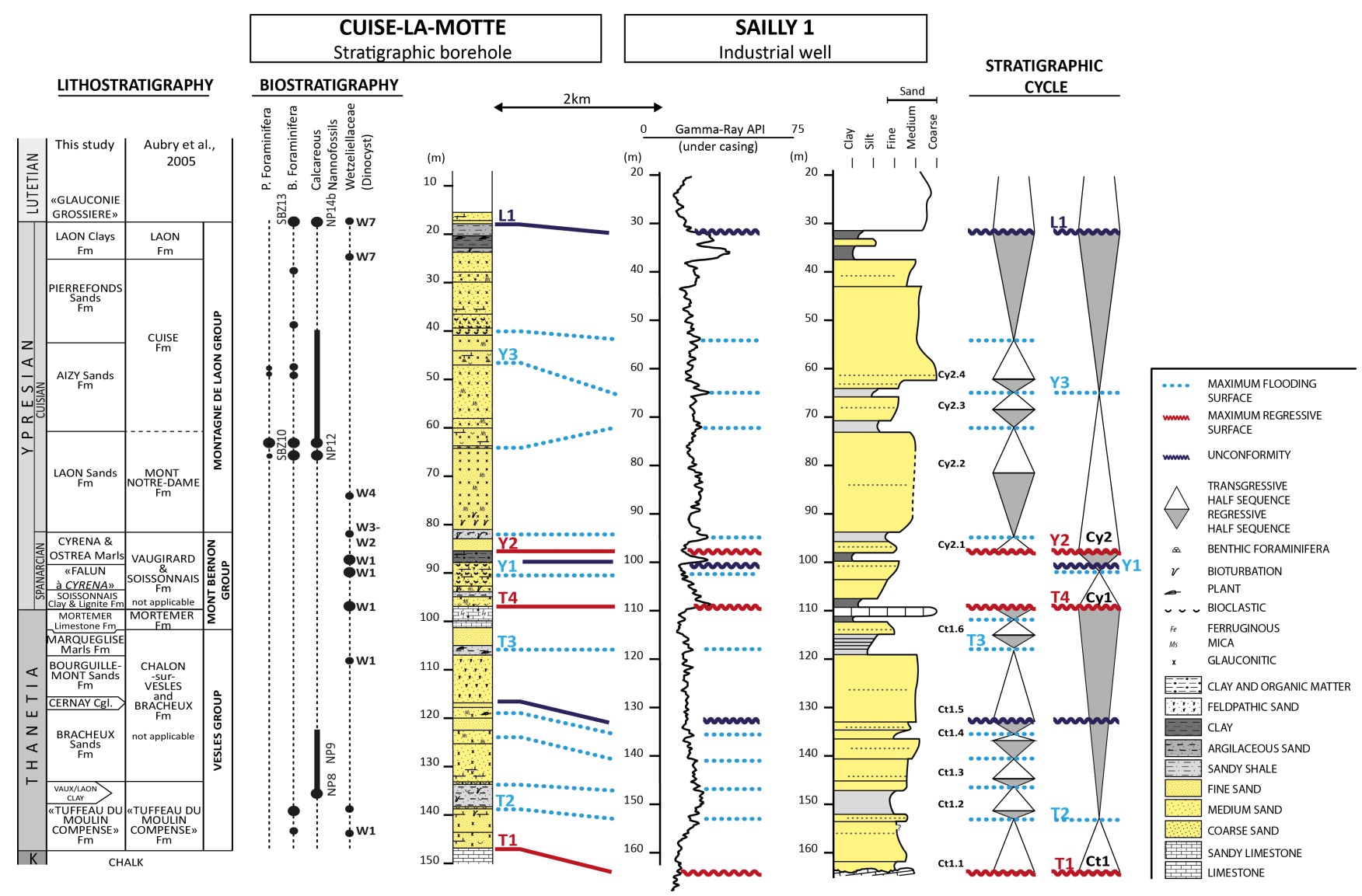

Figure 2. Stratigraphy and sedimentology of the most marine Palaeocene-Lower Eocene sediments of the Paris Basin: the Cuise-la-Motte stratigraphic borehole (Bolin et al., 1982) and the Sailly 1 well. The sequence stratigraphic interpretation is based on both the environmental changes along the Cuise-la-Motte borehole (palaeoecology and sedimentology) and on well-log correlations (see Fig. 4).

- Top MRS (T4): top of the Mortemer Limestones Fm (lacustrine deposits topped by calcrete - FA10) dated by charophytes (long-lasting $P$. discermas zone in the late Thanetian to early Ypresian).

Six fourth-order cycles are defined: 0.5 in the transgressive trend and 5.5 in the regressive trend. The regressive trend is punctuated after the unconformity (above the Bourguillemont Sands Fm) by two marine floodings characterized by: (1) protected marine to brackish clays (Marquéglise Fm T3 marker for the accommodation space measurement), and (2) brackish clays of the Sinceny Fm (Pomerol et al., 1977), just below the Mortemer Limestones Fm. T3 is a major MFS within this regressive trend and could define a cycle of intermediate order within this dominant trend.

The paradox of this cycle is that the MFS T2 time line, corresponding to the deepest sediments, does not correspond to the maximum flooding of the marine facies over the continental domain which occurs at the time of a minor MFS T3 (Fig. 4).

This is explained by a tectonic control on the expression of the Thanetian sedimentation. The evolution of the flex- ure (mainly its relaxation) produces a change in the degree of inclination of the depositional profile, which is steeper after deformation at the beginning of the cycle (i.e during T2) and flatter at the end of the cycle (during T3). Therefore, even if the sea level is higher during $\mathrm{T} 2$, transgression on a steeper surface leads to a less important extension of the marine flooding (Briais et al., 2016).

The age model (Fig. 3 and Table 2) for the Thanetian cycle is mainly based on the chemostratigraphy $\left(\delta^{18} \mathrm{O}\right.$ curve of Cramer et al., 2009), as the orbital solutions are unstable for ages older than 50 Myrs (Laskar et al., 2011; Fig. 3). The biostratigraphic range of the MFS T2 (major) and T3 (minor) fit with two warming events at 58.8 (T2) and $56.9 \mathrm{Ma}$ (T3). The top MRS T4, located before the PETM (see below) corresponds to the cooler event of the end of the Thanetian at 56.4 Ma. The base MRS T1 is only constrained by the range of the short biozone NP7 and was defined at 59 Ma (base of biozone NP7).

The Ypresian 1 (Cy1, T4 to Y2) third-order cycle is mainly made up of bays, marshes, and lakes - i.e. environments close to their base level. 


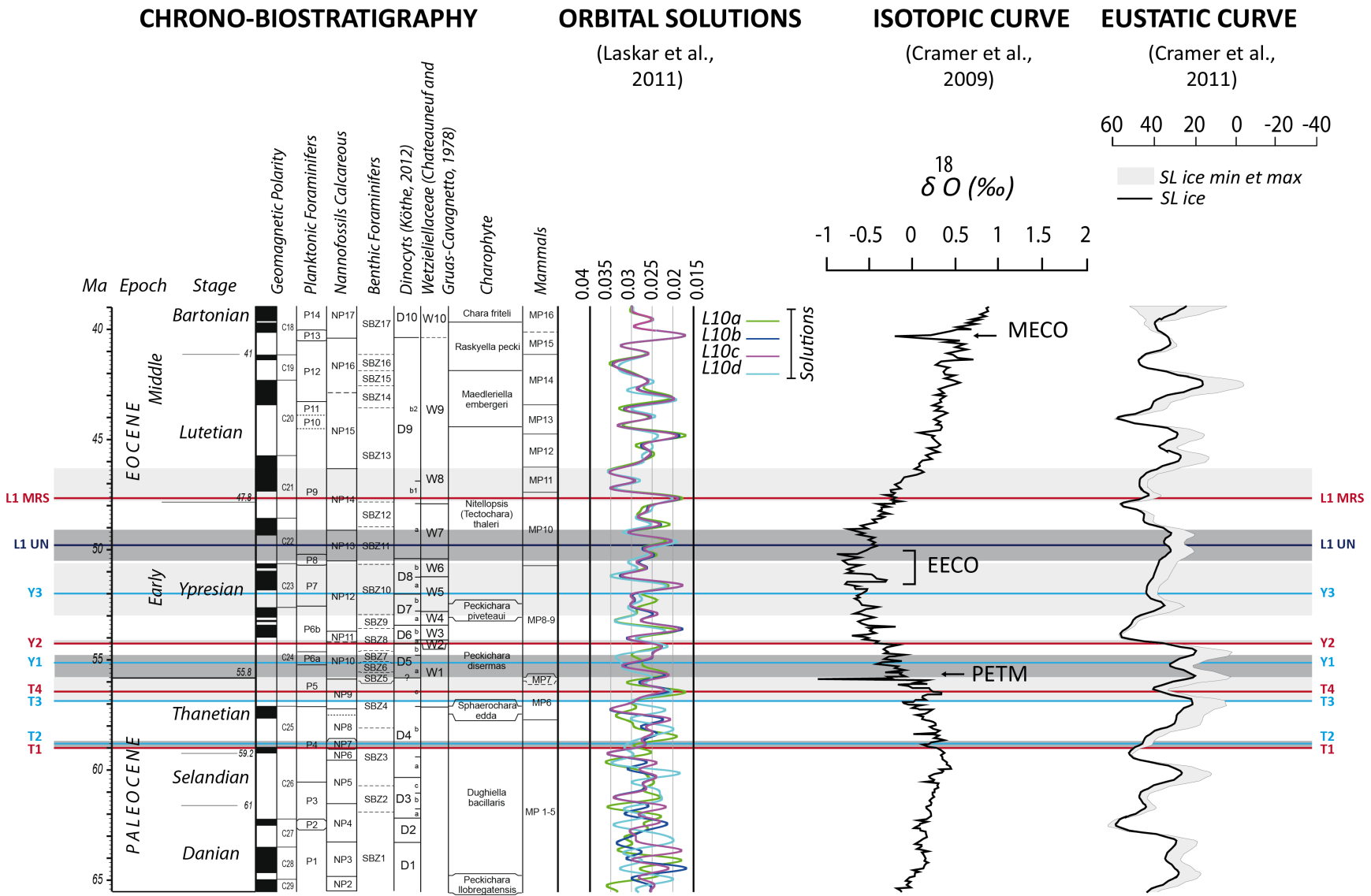

Figure 3. Age model for the Palaeocene-Lower Eocene of the Paris Basin based on re-evaluated biostratigraphic data (this study) calibrated on recent bio-chronostratigraphic charts (Gradstein et al., 2012; Köthe, 2012; Châteauneuf and Gruas-Cavagnetto, 1978; revised in this study) and on the calibration of sequences on both the orbital solutions (Laskar et al., 2011) and isotopic curve (Cramer et al., 2009); see text for discussion and Table 2.

- Base MRS (T4): base of the Soissonnais Clays and Lignites Fm (organic rich marshes - FA8b - to organic-rich lakes); previously dated at 56.4 Ma.

- MFS (Y1): intra "Faluns à Cyrena" Fm (brackish environment - FA8a), dated as the dinocyst zone D6a (Chateauneuf and Gruas-Cavagnetto, 1978, revised here).

- Unconformity: between the "Faluns à Cyrena" and the "Marnes à huîtres et Cyrènes" Fms, there is a sharp transition from brackish to subaqueous fresh water environment (organic rich marshes - FA8b).

- Top MRS (Y2): top of the "Marnes à huîtres et Cyrènes" Fm (FA8), which corresponds in some places (Attichy-Soissons) to characean-rich lacustrine carbonates (FA10).

The transgressive trend is characterized by a well-recorded volumetric facies partitioning (Cross, 1988; Cross and Lessenger, 1998) between thin protected marine deposits (condensation) and "highly" aggradational continental deposits, made up of carbonate lacustrine deposits (FA10) with organic-rich marsh deposits in between. The progradational trend is a stacking of two system tracts bounded by an unconformity. The lower system tract displays the same facies succession as during the transgression. The upper system tract is composed of organic-rich marsh deposits (the Sparnacian lignites described by French stratigraphers) that pass upstream to lacustrine kaolinitic clays, reworking lateritic profiles (Thiry, 1981), the so-called Provins Clays Fm that also gathered the underlying marly clays (Fig. S2).

Due to poor preservation, no fourth-order cycles, which can be correlated along the section, were identified.

The negative carbon isotopic excursion of the PalaeoceneEocene Thermal Maximum (PETM), a marker of the Palaeocene-Eocene boundary, occurred within the Soissonnais Clays and Lignites Fm (Sinceny area in the eastern part of the basin; Quesnel et al., 2011).

The age model for the Ypresian 1 cycle (Fig. 3) is based on both the chemostratigraphy $\left(\delta^{18} \mathrm{O}\right.$ curve of Cramer et al., 2009) and orbital solutions (Laskar et al., 2011). The biostratigraphic range of the MFS Y1 fits with the warming event 


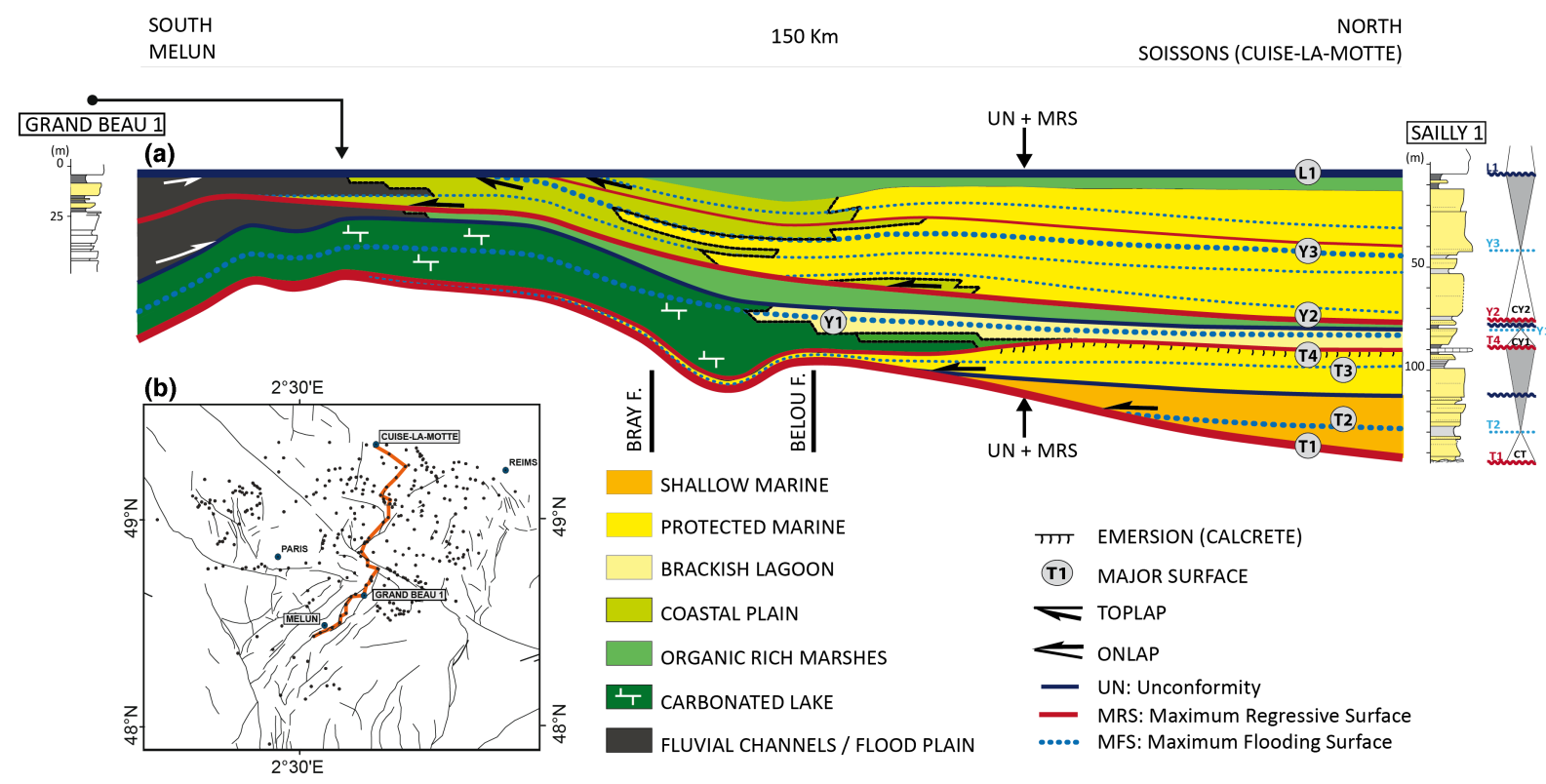

Figure 4. (a) South-north stratigraphic and sedimentological transect (Melun-Cuise-la-Motte) based on well-log correlations using the stacking pattern technique (see Fig. S6) with horizontalization on the MRS of the Lutetian. (b) Location of the section.

at 55.1 Ma and is in the range of the different solutions of a high-eccentricity period described by Laskar et al. (2011). The top of MRS Y2 corresponds to both the cooler event and a low-eccentricity peak at 54.3 Ma.

The Ypresian 2 ("Cuisian", Y2 to L1) third-order cycle is deformed at the end of its depositions and is truncated at this top. The upper limit is paraconformable in the northern part of the basin and tilted-eroded in the southern part. It corresponds to a strong time hiatus before the Lutetian deposition (Pomerol, 1989). The unconformity (UN L1) is thus quite difficult to date in the Paris Basin. This event is very well recorded in the Belgium Basin, the southwestern limit of the North Sea, and is dated within the NP13 biozone (Vandenberghe et al., 2004).

- Base MRS (Y2): base of the Laon Sands Fm, it corresponds to the top of the lacustrine facies overlain by marine to protected marine (FA7) glauconitic micas-rich, fine-to-medium grained sands dated as from the dinocyst zone D6a (Chateauneuf and GruasCavagnetto, 1978, revised here).

- MFS (Y3): intra-Aizy Sands Fm, a marine peak within protected marine environments with marine faunas, e.g. nannofossils and large foraminifers, dated as from the nannofossil biozone NP12 (Aubry, 1983) and the large foraminifer biozone SBZ10 (Bignot and Neumann, 1991).

- Top UN (L1): top of the Laon Clay Fm, more or less organic-rich clays with sands deposited in a large coastal (to alluvial) plain, dated as NP13 by analogy with Belgium (see above).

This cycle shows similar facies (the Cuisian facies described by French stratigraphers) during both the transgressive and regressive trends. They evolve from a depositional setting in large bays, more or less protected from waves and sometimes dominated by tides (large estuaries), passing laterally to coastal plains (FA8a - "Fausses glaises" Fm) and then fluvial flood plains (FA9 - Villenauxe, Monpothier, and Breuillet Sandstones Fms). The time line Y3 corresponds to the major marine flooding of the continental domain followed by the progradation of the coastal plain deposits (Fig. 4).

Four higher-order cycles were defined (Cy2.1 to Cy2.4).

The age model for the Ypresian 2 cycle (Fig. 3) is based on both the chemostratigraphy and orbital solutions. The biostratigraphic range (NP12) of the MFS Y3 fits with the warming event at $52 \mathrm{Ma}$ and is in the range of the different solutions of a high-eccentricity period described by Laskar et al. (2011). The top MRS L1, in the sense of the first flooding, is dated NP14 (Aubry, 1983) and corresponds to both the cooler event and a low-eccentricity peak at 47.8 Ma.

\section{Accommodation space measurement along the $\mathbf{S}-\mathbf{N}$ transect (Melun-Soissons transect)}

The accommodation space was measured on eight time lines (T1 to L1), defined above, and 31 wells that compose the S-N transect, crossing two faults: the major Bray Fault and the Belou Fault (Fig. 5). The data set is available in Figs. S1 and S7. 
Table 2. Age model for the bounding cycles of the stratigraphic surfaces (MFS, MRS, and Unconformities).

\begin{tabular}{|c|c|c|c|c|}
\hline $\begin{array}{l}\text { TIME- } \\
\text { LINES } \\
\text { (number, } \\
\text { nature) }\end{array}$ & LITHOSTRATIGRAPHY & BIOSTRATIGRAPHY & $\begin{array}{l}\text { TIME INTER- } \\
\text { VAL } \\
\text { (Gradstein et al., } \\
\text { 2012) }\end{array}$ & $\begin{array}{l}\text { PROPOSED DATE } \\
\text { cyclostratigraphy }{ }^{1} \\
\text { chemostratigraphy }\end{array}$ \\
\hline L1 MRS & "Glauconie Grossière” Fm & NP: NP 14 (Aubry, 1983) & $47.8-46.3 \mathrm{Ma}$ & $47.8 \mathrm{Ma}^{1,2}$ \\
\hline UN & $\begin{array}{l}\text { by analogy with Belgium = intra } \\
\text { NP13 }\end{array}$ & $\begin{array}{l}\text { BF: SBZ13 (Blondeau, 1965) } \\
\text { D: W7 (D9a?; Chateauneuf } \\
\text { and Gruas Cavagnetto, 1978; } \\
\text { revised) }\end{array}$ & $50.5-49.1 \mathrm{Ma}$ & $49.8 \mathrm{Ma}$ \\
\hline Y3 MFS & Aizy Sands Fm & $\begin{array}{l}\text { CN: NP12 (Aubry, 1983) } \\
\text { BF: SBZ10 (Bignot and Neu- } \\
\text { mann, 1991) }\end{array}$ & $53-50.6 \mathrm{Ma}$ & $52 \mathrm{Ma}^{1}$ \\
\hline Y2 MRS & Laon Sands Fm (base) & $\begin{array}{l}\text { D: W2 (D6a; Chateauneuf and } \\
\text { Gruas Cavagnetto, 1978; re- } \\
\text { vised) }\end{array}$ & $54.3-54.1 \mathrm{Ma}$ & $54.3 \mathrm{Ma}^{2}$ \\
\hline Y1 MFS & "Falun à Cyrena" Fm & $\begin{array}{l}\text { D: W1 (D5a; Chateauneuf and } \\
\text { Gruas Cavagnetto, 1978; re- } \\
\text { vised) }\end{array}$ & $55.8-54.8 \mathrm{Ma}$ & $55.075 \mathrm{Ma}^{1}$ \\
\hline T4 MRS & Mortemer Limestone Fm & $\begin{array}{l}\text { C: P. disermas (Pomerol and } \\
\text { Riveline, 1975) }\end{array}$ & $56.9-55.8 \mathrm{Ma}$ & $56.4 \mathrm{Ma}^{1}$ \\
\hline T3 MFS & Marqueglise Marls Fm & $\begin{array}{l}\text { D: W1 (D4c; Chateauneuf and } \\
\text { Gruas Cavagnetto, 1978; re- } \\
\text { vised) }\end{array}$ & $56.9-55.8 \mathrm{Ma}$ & $56.9 \mathrm{Ma}^{2}$ \\
\hline T2 MFS & $\begin{array}{l}\text { "Tuffeau du Moulin Compensé" } \\
\text { Fm }\end{array}$ & $\begin{array}{l}\text { CN: NP7 (Steurbaut, 1998) } \\
\text { D: W1 (D4b; Chateauneuf and } \\
\text { Gruas Cavagnetto, 1978; re- } \\
\text { vised) }\end{array}$ & $59-58.7 \mathrm{Ma}$ & $58.8 \mathrm{Ma}^{2}$ \\
\hline $\begin{array}{l}\text { T1 } \\
\text { UN/MRS }\end{array}$ & $\begin{array}{l}\text { "Tuffeau du Moulin Compensé" } \\
\text { Fm (base) }\end{array}$ & $\begin{array}{l}\text { CN: NP7 (Steurbaut, 1998) } \\
\text { D: W1 (D4b; Chateauneuf and } \\
\text { Gruas Cavagnetto, 1978; re- } \\
\text { vised) }\end{array}$ & & $\begin{array}{l}59 \mathrm{Ma}^{2} \\
\text { (base, NP7) }\end{array}$ \\
\hline
\end{tabular}

MFS: Maximum flooding surface; MRS: Maximum regressive surface; Un: Unconformity; CN: Calcareous Nannofossils; D: Dinocyst and Wetzeliellaceae; C: Charophyte; M: Mammals; BF: Benthic Foraminifera; ${ }^{1}$ Laskar et al. (2011), ${ }^{2}$ Cramer et al. (2009).

The observed facies are quite high wave-energy facies and a fair-weather wave base between -20 and $-15 \mathrm{~m}$ is realistic. Thus, from the shoreline to proximal upper offshore deposits, two palaeodepth hypotheses were tested: between 0 and $-20 \mathrm{~m}$ and 0 and $-30 \mathrm{~m}$. For inner estuarine and protected marine environments (more or less tidal-influenced embayments), well-log correlations show persistent electrofacies over large distances, suggesting relatively flat profiles, and have been ranked between -5 and $0 \mathrm{~m}$. The coastal plain has an elevation of a few metres above mean sea level. The palaeoelevation was estimated between $0 \mathrm{~m}$ (at the shoreline) up to $+10 \mathrm{~m}$, close to the transition to more fluvial deposits.

Different hypotheses (minimum and maximum) regarding the compaction and the palaeodepth are tested on the Cuisela-Motte well (see Fig. S8). The curves for the different hypotheses are very similar to each other. Thus, uncertainties on the palaeodepths and decompaction do not significantly influence the measured accommodations.

Two types of graphs are compiled here: the cumulated accommodation space (Fig. S9) and the accommodation space variation between each time line (Fig. 5), both of which are found along the 31 wells of the S-N regional transect (Fig. 4), using the minimum compaction hypothesis.

The accommodation space rate varies along the transect (Fig. 5), regardless of the which time slice is analysed, suggesting a local (multiple of $1 \mathrm{~km}$ ) to medium (multiple of $10 \mathrm{~km}$ ) wavelength tectonic control. At the transect scale, the accommodation space rate varies from north to south. It is constantly higher in the north during the Thanetian while a different pattern is observed during the Ypresian Cy1 where the Bray and Belou faults control the accommodation rate distribution. During the Ypresian Cy2, the distribution is more similar to the Thanetian distribution.

The accommodation rate varies between 60 (creation) and $-5 \mathrm{~m} \mathrm{Ma}^{-1}$ (removal). The highest rate $\left(60 \mathrm{~m} \mathrm{Ma}^{-1}\right)$ is probably unlikely. This results from poorly constrained MRS age (T1) and the maximum rate value is probably lower.

1. The Thanetian cycle $(\mathrm{T} 1-\mathrm{T} 4, \mathrm{Ct})$ is characterized during its transgressive period (T1-T2) by a marine onlap, which means no creation of accommodation space in the continental area, north of the Belou Fault, and by a sharp increase of accommodation space toward the north to 

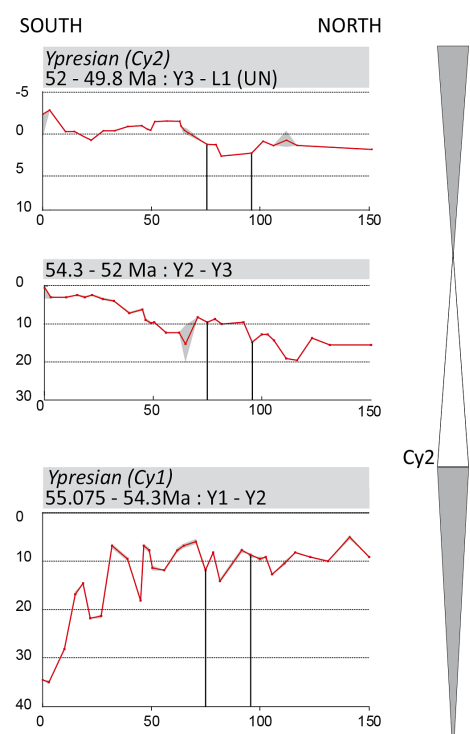

$56.4-55.075 \mathrm{Ma} \cdot \mathrm{T} 4-\mathrm{Y} 1$

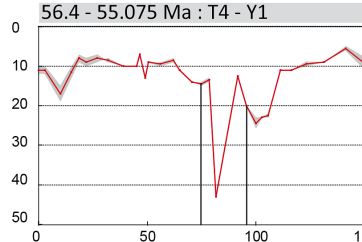

Thanetian (Ct) $56.9-56.4 \mathrm{Ma} \cdot \mathrm{T3}-\mathrm{TH}$

-20
-10
0
10
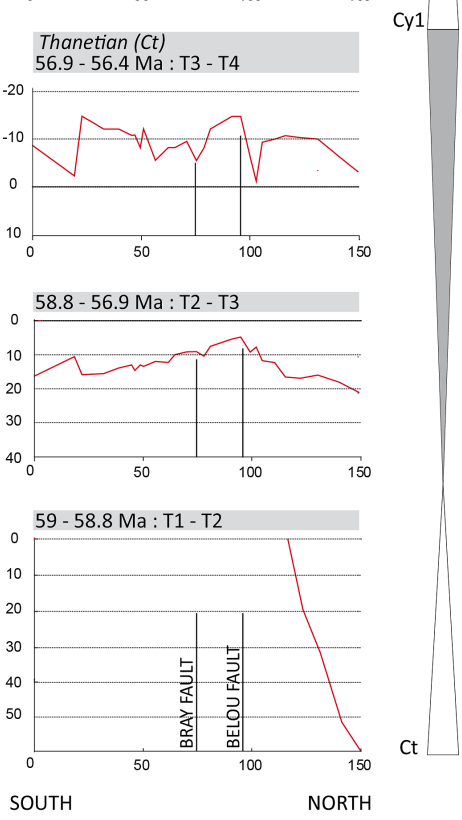

WELL-LOG POSITION (Km)

Figure 5. Accommodation space rate $\left(\mathrm{m} \mathrm{Ma}^{-1}\right)$ for Palaeoceneearly Eocene times along the south-north transect (Fig. 4) for each time interval. Each curve (red line) represents the accommodation space. Error bars (in grey) take different compaction rates into account (see Fig. S8). a (questionable) maximum of $60 \mathrm{~m} \mathrm{Ma}^{-1}$ (Soissons). The regressive trend was split into two time intervals to better constrain the accommodation variations during this period, within which maximum onlap occurs (T3). From T2 to T3, the accommodation rate is positive and subdivided into two domains by the Bray/Belou faults. From T3 to T4, the accommodation rate is negative with variable values around -5 to $-15 \mathrm{~m} \mathrm{Ma}^{-1}$. The negative accommodation period is coeval with a forced regression wedge in the Belgian basin (Steurbaut, 1998; Vandenberghe et al., 2004). In the Paris Basin, it is only recorded by an emersion (calcrete) at the top of Mortemer Limestones Fm. No erosion and incision is recorded in the Paris Basin, probably due to the flat profile.

2. Ypresian 1 cycle (T4-Y2, Cy1) is characterized by quite low values (around $10 \mathrm{~m} \mathrm{Ma}^{-1}$ ), which are slightly higher during the transgressive trend (T4-Y1). The accommodation rate is quite homogeneous, except between the Bray and Belou faults for the transgressive period where much higher values are measured (up to $\left.45 \mathrm{~m} \mathrm{Ma}^{-1}\right)$. The regressive trend (Y1-Y2) of the Ypresian 1 cycle records a major change in the regional accommodation rate trend with higher values in the formerly poorly subsiding southern part. This time interval records a unique inversion of accommodation space distribution, located southward, i.e. toward the continent. High accommodation rate is recorded by high thickness of fluvial sediments deposited in a regressive trend thanks to a high local subsidence.

3. Ypresian 2 cycle (Y2-L1, Cy2) is more homogeneous with accommodation creation during the Y2-Y3 interval and maximum accommodation in the northern part (10-15 $\left.\mathrm{m} \mathrm{Ma}^{-1}\right)$. During the regressive trend Y3-L1, the values are lower (around zero) and more homogeneous. Accommodation is higher between the Bray and Belou faults.

The top Ypresian unconformity records a minimum value of approximately $-5 \mathrm{~m} \mathrm{Ma}^{-1}$ of accommodation space removal in the southern part of the transect, reflecting erosion before Lutetian sedimentation. Here, the eroded decompacted thicknesses are estimated from preserved thicknesses in the northern part and from sedimentary geometries (toplap) showing a truncation (Fig. 4).

Considering that transgression-regression are controlled by $A / S$ ratio (accommodation/sediment flux), we can propose from our accommodation measurement that:

- the Thanetian (T1-T4) and Ypresian 2 (Y2-L1) cycles are clearly controlled by accommodation space variations, which are positive and "higher" during the transgressive period and positive (low) to negative at the end of the regressive hemicycle. 
- In contrast, the Ypresian 1 (T4-Y2) cycle, with low accommodation variations between the transgressive and regressive hemicycles, is probably more controlled by an increase in the sedimentary flux during the induced regressive trend.

\subsection{Basin-scale data}

\subsubsection{Major discontinuities of the uppermost Cretaceous-early Palaeocene (base of the late Campanian to the base of the Thanetian -76 to 59 Ma)}

Since the works of Bertrand (1892) and Lemoine (1911), major unconformities with a deformation and hiatuses corresponding to a major change in the depositional system (chalk vs. shallow marine sandstones) are well known in the Paris Basin. Paradoxically, because of its long wavelength, few studies have been carried out on this kind of deformation. In further detail, this deformation pattern is much more complex. This period corresponds to a major decrease in the Paris Basin subsidence that needs to be understood when dealing with Paleaogene deformations.

In details, this deformation is characterized by two time hiatuses separated by a sedimentation phase during the Danian. Our main concern here is to evaluate whether there is a continuity in subsidence regime from the latest Cretaceous to Thanetian sedimentation.

To better understand the nature and origin of the deformation occurring during this time interval, we compiled and compared different types of maps over an area larger than the studied area (up to Belgium): (1) a basin-scale map illustrating the geometrical relationships between the tabular Palaeocene to Middle Eocene deposits over the tilted late Cretaceous to Jurassic sediments (Fig. 6); (2) a subcrop map of the age of the chalk below dated occurrences (wells and mainly outcrops) of middle/late Danian and Thanetian sediments (Fig. 7b), (3) a location map of the dated Danian sediments (Fig. 7b); these maps are compared with (4) a thickness map of the Thanetian cycle (Fig. 7a), and (5) an age map of the base of the Thanetian sediments, to better understand the basal onlap (Fig. 7b).

The large-scale structural map, showing the relationships between the tabular Cenozoic sediments and the underlying Mesozoic sedimentary rocks (Fig. 6), suggests that the present-day ring-like structure is pre-Ypresian in age. Along the Ardennes Massif, silcrete overlain by early Ypresian sediments (Quesnel, 2003) known as "Pierre de Stonne" (Voisin, 1988) overlap all the tilted Jurassic to Cretaceous sedimentary rocks.

The subcrop map (Fig. 7b) at the base of the Palaeocene indicates that (1) no sediments younger than the basal late Campanian (top of the planctonic foraminifera biozone Contusotruncanna plummerae - see Fig. S3) are preserved in the central part of the Paris Basin, while reworked Maas- trichtian faunas and deposits (flints with foraminifers) are known at the base of the Thanetian (Blanc and Guillevin, 1974; Quesnel et al., 1996). (2) These youngest chalk are all preserved below Danian outcrops which are located in isolated areas as lenses (Fig. 7b). Danian sediments show the same facies: bioclastic algal limestones in shallow subaqueous conditions (Bignot, 1993; Montenat et al., 2002). Paradoxically, Danian sediments are the most marine deposits of all the Cenozoic deposits, but are only preserved as scattered occurrences both in the outcrops and subsurface. (3) Ages of preserved chalk below Thanetian are older in the northern part and particularly on the Artois anticline (eastern prolongation of the Weald-Boulonnais anticline) suggesting more pronounced uplift where Thanetian sediments overlain Turonian chalk while Campanian and Maastrichtian deposits are preserved in the Mons basin nearby.

The isopach map (Fig. 7a) and the map of basal ages (Fig. 7b) of the Thanetian suggests a completely different pattern: (1) a change in the subsidence distribution with two domains of sediments accumulations (along the FranceBelgium borders to the north, and in the Soissons area to the south), and (2) onlaps with a similar spatial distribution as the depocentres. The Artois anticline (eastern prolongation of the Weald-Boulonnais anticline) is inverted: from an uplifted domain before the Thanetian (Fig. 6) to a subsiding one during the Thanetian (Fig. 7a).

\subsubsection{Late Palaeocene-early Eocene sediment thickness (isopach) maps, proxy of the accommodation space: 3-D evolution (Fig. 8)}

Seven isopachs maps were drawn (Fig. 8), six for each half cycle of the three third-order cycles (Ct, Cy1, Cy2) and one for the last fourth-order cycle (Cy2.4) of the regressive trend of the second Ypresian cycle (Cy2), in order to discuss the erosion of the late Ypresian unconformity.

The Thanetian $(\mathrm{Ct})$ third-order cycle has been subdivided into two time intervals (T1-T3 and T3-T4) that do not correspond to the hemicycles for a better understanding of the deformation. The first map shows the distribution of the first Thanetian deposits, following the pre-Thanetian deformation. It reveals a flexure with a maximum thickness located to the north of the Bray Fault. The second map shows a more homogeneous subsidence pattern that accompanies the maximum onlap.

The subsidence spatial distribution of the first Ypresian (Cy1) third-order cycle, characterized by low accommodation space creation (around $10 \mathrm{~m} \mathrm{Ma}^{-1}$ ), is much more heterogeneous, with several patchy domains with a wavelength of few tens of kilometres related to fault reactivation. The transgressive (T4-Y1) and regressive (Y1-Y2) trends are very different. From T4 to Y1, subsidence is at its maximum near the Belou and Bray Faults, especially along a NE-SW corridor situated in the prolongation of the Hurepoix Block bounded by the Seine-Valpuiseaux and Rambouillet faults 


\section{SUBCROP MAP AT THE BASE OF THE EARLY-MID EOCENE}

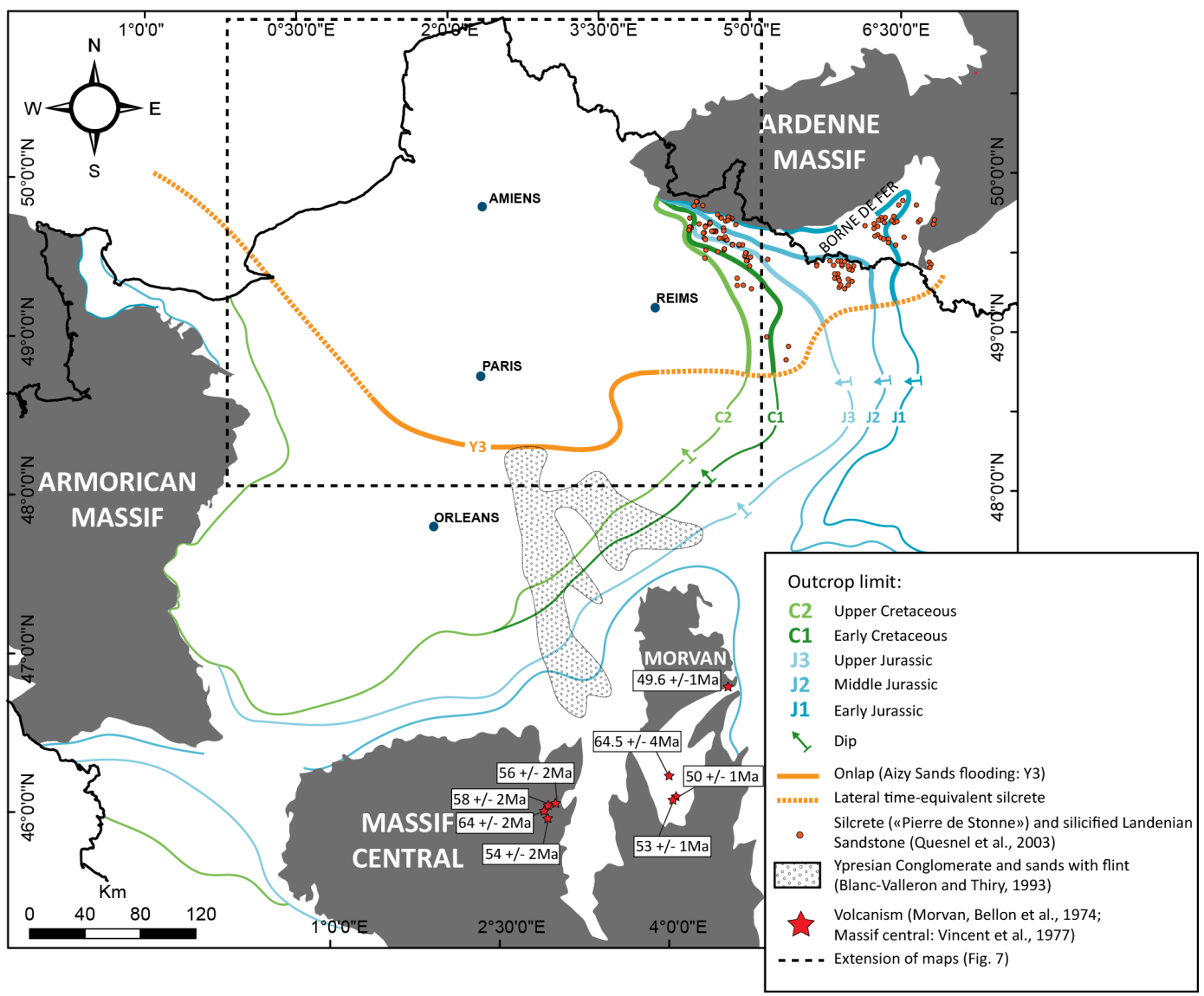

Figure 6. The uppermost Cretaceous-Palaeocene deformations of the Paris Basin. Geometrical relationship between Palaeocene-Lower Eocene sediments and tilted Jurassic to late Cretaceous sedimentary rocks.

(Fig. 1). Conversely, during the regressive trend (Y1-Y2), the trend of the subsidence is inverted, meaning that the previous areas of maximum subsidence are now the areas of minimum subsidence. Maximum subsidence is observed south of the Hurepoix Block.

The second Ypresian (Cy2) third-order cycle displays a similar pattern as the Thanetian cycle with a large flexure and a maximum subsidence to the north in the Soissons area. Except for cycle Cy1, the Paris area between the Seine and Bray faults is subsiding, as well as in the Beauce area. The uppermost Ypresian unconformity can be documented on the isopach map of the preserved deposits of the fourth-order cycle Cy2.4: the major erosion (main uplift) is located south of the Bray Fault along an E-W trend.

\subsubsection{Late Palaeocene-early Eocene palaeogeographical maps: main changes in the sedimentary systems (Fig. 9)}

Three facies maps (Fig. 9) were compiled along three MFS (T3, Y1, and Y3), based on the well-log electrofacies defined in Fig. S5.

The Thanetian fourth-order maximum flooding surface T3 (Marquéglise Marls Fm - 56.9 Ma) map is only made up of one facies, corresponding to protected marine deposits. This marine domain passed laterally to an area of no deposition (hiatus), probably with fluvial bypassing. This fourth-order MFS corresponds to the maximum marine flooding over the continent.

The third-order maximum flooding surface $\mathrm{Y} 1$ of the first Ypresian cycle (Cy1) is characterized by a large brackish domain ("Falunà Cyrena" Fm - 55.1 Ma) passing upstream to a large carbonate lacustrine domain and then to classical fluvial systems with flood plains to the west. 

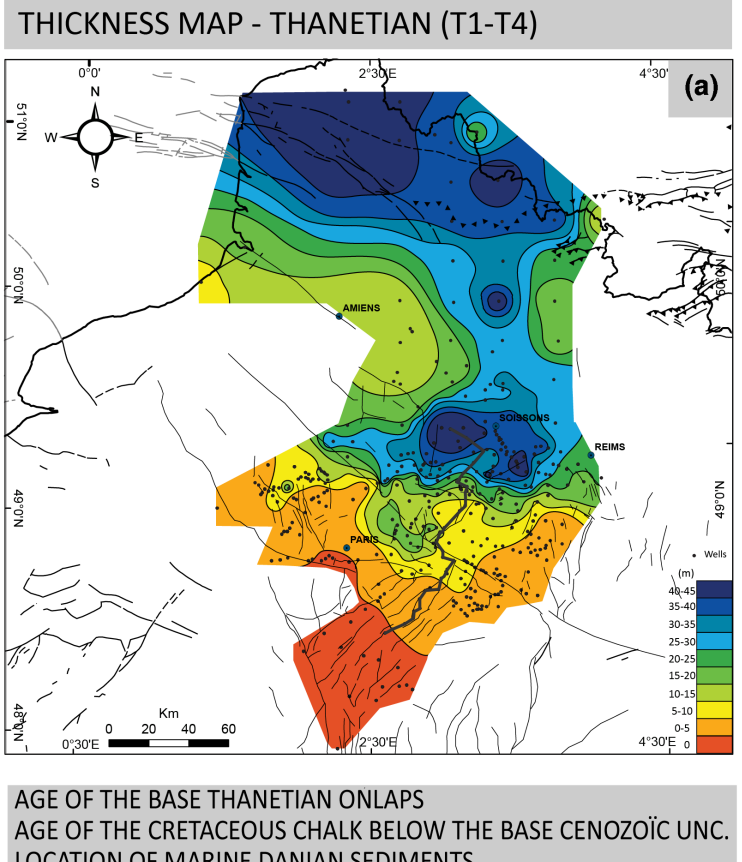
LOCATION OF MARINE DANIAN SEDIMENTS

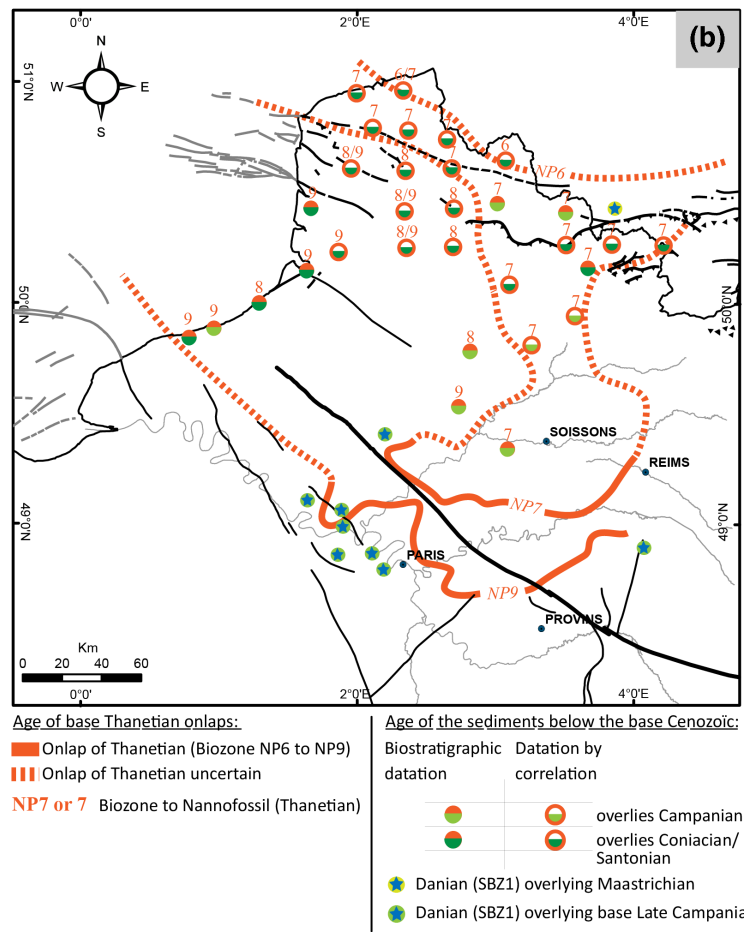

Figure 7. Upper Palaeocene sediment distribution in the Paris and Belgium (Bruxelles) basins. (a) Isopach map of the Thanetian cycle (T1-T4; data from this study and geological maps of France at the $1: 50000$ scale). (b) Age of the Thanetian onlaps and Upper Cretaceous (chalk) sediments below the base of the Cenozoic and the location of the marine Danian sediments (data from geological maps of France at the 1:50000 scale).
The third-order maximum flooding surface Y3 of the second Ypresian cycle (Aizy Sands Fm - 52 Ma) corresponds to a protected marine domain with bays and aprons confirming the wave-protected nature of this domain, except for more open marine environments along the Bray Fault. They pass southward to coastal and alluvial plains.

These three periods represent three different depositional profiles. The Thanetian (wave-dominated) and Ypresian profiles (protected marine) are classical and extensively documented in the literature. The basal Ypresian profile is more original and reflect flat profile, such as the current large coastal plain of Florida.

\section{Discussion}

\subsection{Sea level variations during Palaeogene times and stratigraphic cycle controls}

Several sea level curves have been published, which differ from one to the other: (1) Haq et al. (1987), (2) Miller et al. (2005), (3) Müller et al. (2008) (4) Cramer et al. (2011) and (5) Rowley (2013).

1. Haq's data set was never published but, for the Cenozoic, it is based on European basins where longwavelength deformation is quite significant.

2. The 1-D accommodation record filtered from the longterm subsidence, in a place (New Jersey) where the dynamic topography due to the Pacific subduction is significant (Raymo et al., 2011), cannot be the record of eustasy.

The other types of curves - (3), (4) and (5) - agree for a mean sea level of approximately $50 \mathrm{~m}$ above the present-day sea level for the Palaeocene-early Eocene with: (1) few variations at a timescale of few tens of millions years $(\times 10 \mathrm{Ma})$, and (2) an amplitude for the sea level variations of $20-30 \mathrm{~m}$ for a timescale of several $400 \mathrm{Kyrs}$ (Cramer et al., 2011).

The only third-order cycle that could be enhanced by eustasy is the Sparnacian 1 (Cy1) cycle bounded by two MRS that correspond (Fig. 3) to cooler events on the isotopic curve of Cramer et al. (2009) and then to the beginning of the sea level rise after two significant peaks of sea level fall on the eustatic curve of Cramer et al. (2011). However, this view is not totally supported by the accommodation space rate (Fig. 5). The accommodation space is quite homogeneous along the $\mathrm{S}-\mathrm{N}$ transect (except along the Bray-Belou Fault for the transgressive trend and southward of the Hurepoix Block for the regressive trend), with a few differences in the mean accommodation rate between the transgressive and regressive hemicycles that suggest sedimentary flux influence. possibly enhanced by strong climate variations.

Considering fourth-order cycles with characteristic duration of 400 (or multiple of $400 \mathrm{Kyrs}$ ), we assume a dominant climato-eustatic control in agreement with the present-day 

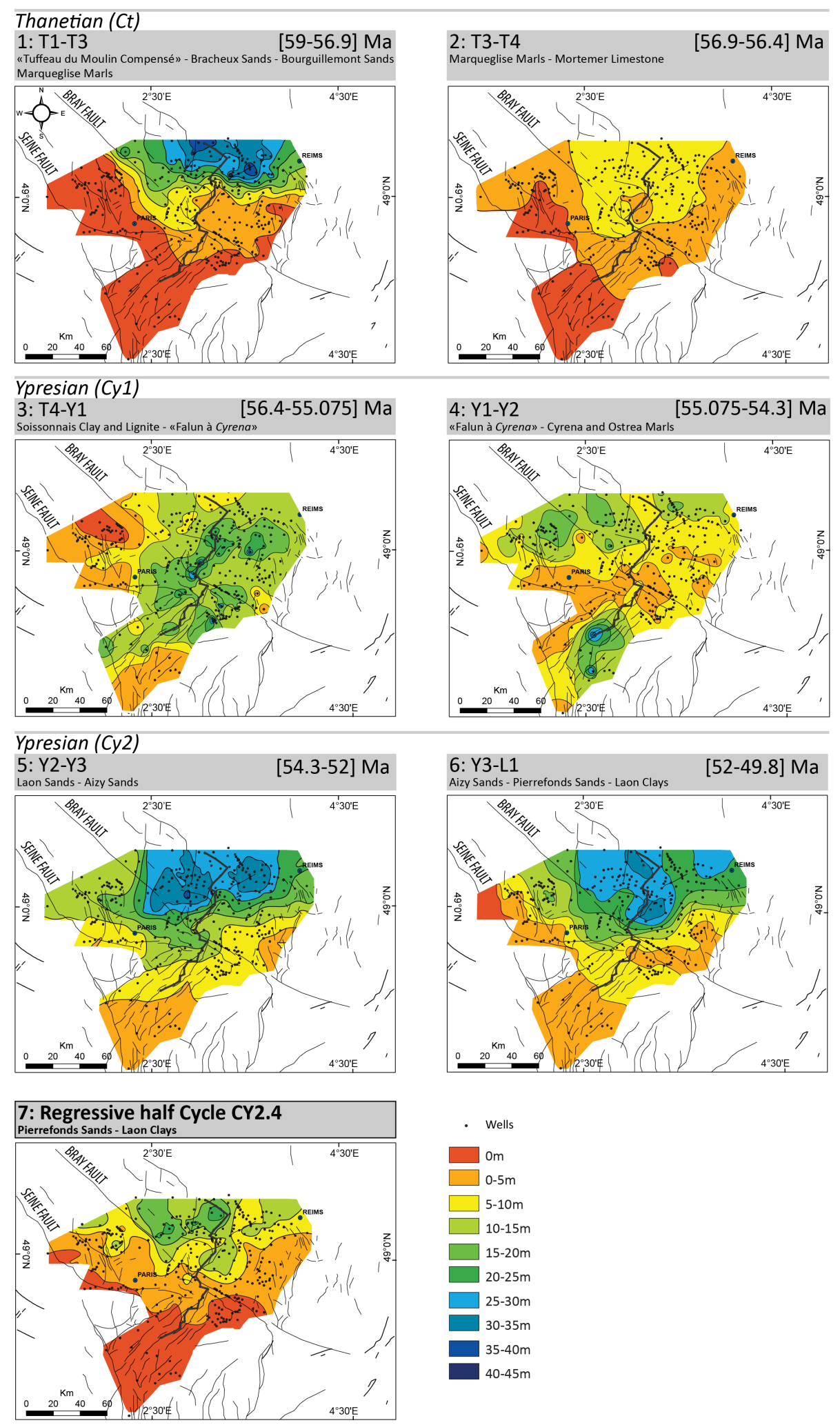

Figure 8. Isopach (sediment thickness) maps for each transgressive or regressive hemicycle of the three third-order cycles: Thanetian (Ct), Ypresian 1 (Cy1), Ypresian 2 (Cy2), and for the last fourth-order cycle of the regressive trend of Cy2, illustrating the erosion during the late Ypresian unconformity. 

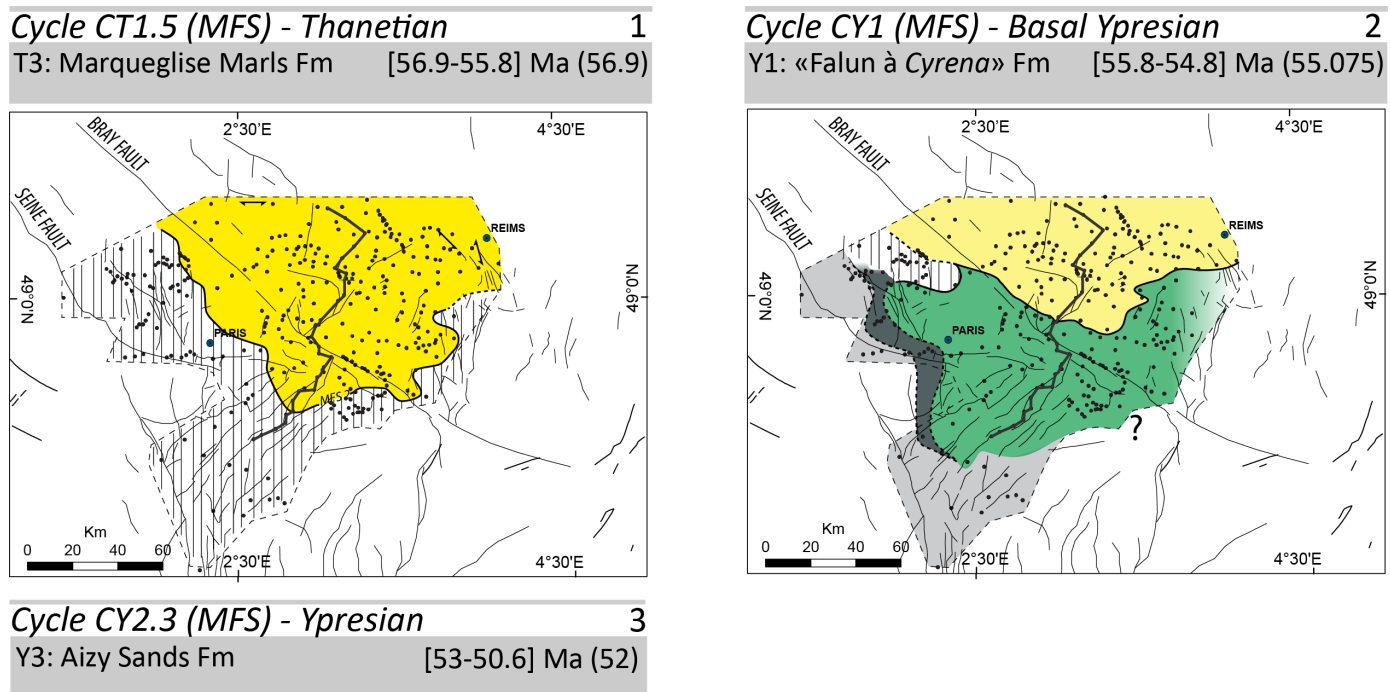
3
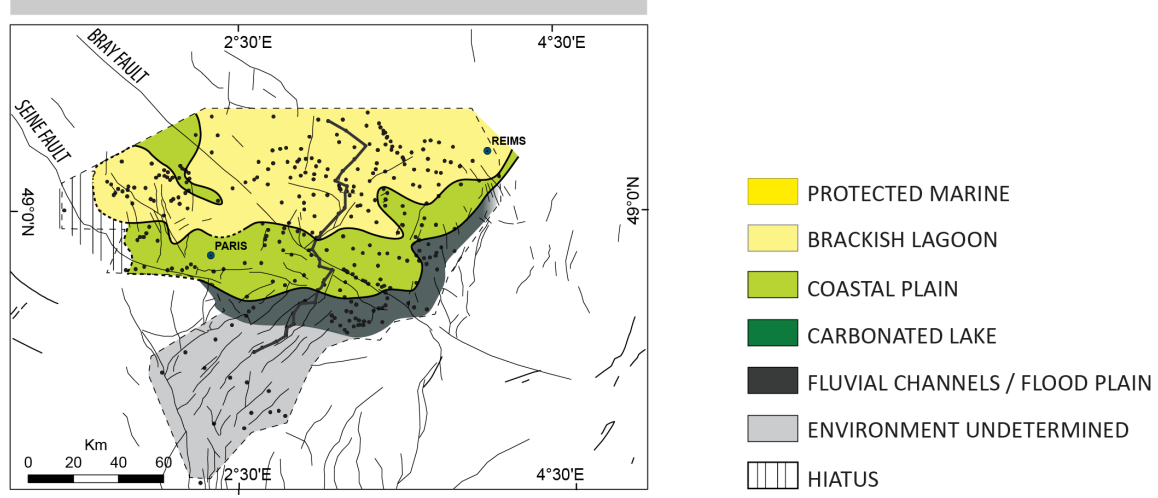

Figure 9. Palaeogeographic (facies) maps for some maximum flooding surfaces of the Thanetian (T3) and Ypresian (Y1 and Y3).

knowledge of the importance of long-term eccentricity cycles on the stratigraphic record (Strasser et al., 2000; Boulila et al., 2011).

\subsection{Meaning of the Paris Basin deformations at European scale}

Three main periods of deformation were characterized from the 2-D accommodation measurement (Fig. 5) and the 3-D sediment thickness maps (Fig. 8):

- Intra-Maastrichtian-pre-Thanetian (T1, 59Ma): This deformation phase is probably composed of two superimposed deformations: Maastrichtian-pre-middle Danian and Upper Danian-pre-Thanetian. These deformations are difficult to decipher and restore, but result in a long-wavelength deformation with the formation of the present-day ring shape of the Paris Basin, its emersion, and a major change in the sedimentary systems (Fig. 10b).

- early Ypresian (T4-Y2, 56.4-54.3 Ma): mediumwavelength inversion of the Hurepoix Block and, at 55. $1 \mathrm{Ma}$, initiation of the southward-migrating flexure.
- Uppermost Ypresian (L1-intra-NP 13, mean 49.8 Ma): uplift of the Paris Basin at a long wavelength $(\times 100 \mathrm{~km})$ corresponding to the emersion of the whole basin.

Microtectonic data measured in the Paris, Belgium, and London basins do not show evidence of stress changes around these periods. Depending on the area, the Palaeocene is either more compressional (Blés et al., 1989, northern French Massif Central; Rocher et al., 2004; André et al., 2010, eastern Paris Basin) or transpressional (Vandycke, 2002, Belgiumnorthern Paris Basin). Except for Belgium, no age constraints are provided.

The best way to discuss the wavelength and then the spatial distribution of these deformations is to do a comparison with other basins of Western Europe (Fig. 10a) and to identify the tectonic-related unconformities of the same age.

The intra-Maastrichtian-pre-Thanetian deformation is a European-scale unconformity recording more or less significant deformations (Fig. 10a). In the Aquitaine Basin (SW France), a flexure of the North Aquitaine platform is recorded during the Maastrichtian (Platel, 1996), In Provence (SE France), Pyreneo-Provençal deformations are sealed by Da- 

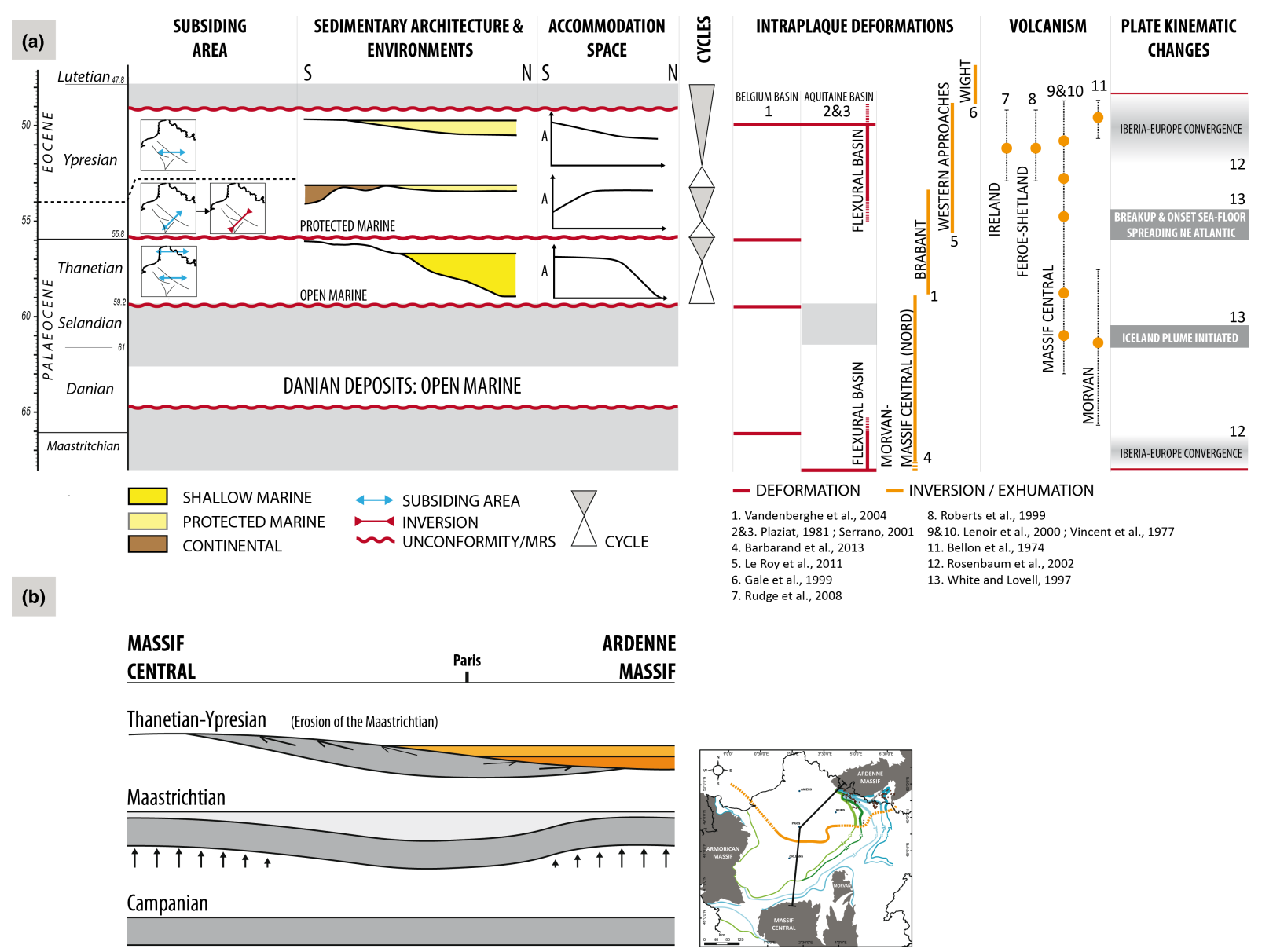

Figure 10. Evolution of the deformation of the Paris Basin during Palaeocene-Lower Eocene times - comparison with the surrounding domains: (a) Synthetic chart. (b) Deformation evolution along a N-S transect from the Ardennes Massif and the French Massif Central.

nian continental facies (Leleu, 2005). A second, more subtle deformation occurs in the southwestern part of the Aquitaine Basin (Serrano, 2001), during late Selandian times. In Belgium, Maastrichtian and Danian strike-slip movements have been evidenced in the Mons Basin (Vandycke et al., 1989; Vandycke and Bergerat, 2001). In the Roer Valley graben (NW Germany to The Netherlands and Belgium), the main deformation is around the Danian-Selandian stages (Deckers et al., 2014) with a major relative sea level fall and formation of a Danian lowstand wedge (Jacob and De Batist, 1996; Vandenberghe et al., 2004). In the Wessex-Hampshire basins, the uppermost Selandian sediments (Thanet Sands) rest unconformably over the deformed chalk (Aubry, 1986; Knox, 1996; Newell, 2001). The Palaeocene is a time of large exhumation in the British Isles with associated turbitic fans related to Iceland plumes (White and Lovell, 1997).

In western Europe, these intra-Maastrichtian-preThanetian deformations, known as Laramide deformations (Ziegler, 1990), are related to either (1) the opening of the North Atlantic and the Faroe-Shetlands-Greenland volcanic trap (Iceland doming; Doré et al., 1999; Anell et al., 2009;
White and Lovell, 1997) or (2) a compressional event; the Africa, Iberia, Eurasia convergence (Ziegler, 1990). The purpose of this present work is not to discuss the relative importance of these two processes, which could only be a local record of a more Earth-scale plate (and then mantle circulation) reorganization. Irrespective of the mechanism, it is clear that compressive deformations affect southern France around the Cretaceous-Cenozoic boundary (before Danian) and that Palaeocene to early Eocene volcanism (Fig. 10a) is widespread in western Europe: the FaroeShetlands-Greenland flood basalts (Mussett et al., 1988; Knox, 1996), the French Massif Central (Bellon et al., 1974; Vincent et al., 1977), and the Rhenish Massif (Baranyi et al., 1976; Schmitt et al., 2007; Reischmann et al., 2011).

The early Ypresian deformation is located in northwestern Europe. It does not exist in the Aquitaine Basin, or in the Wessex-Hampshire basins. In Belgium, an uplift of the Brabant Massif is documented from the Thanetian to the early Ypresian (Vandenberghe et al., 2004). Graben inversions in the St George's Channel (Anell et al., 2009) and of the Western Approaches (Le Roy et al., 2011) are reported in this time 
interval and are probably related to the onset of the North Atlantic opening that takes place at this time (Fig. 10a). However, the occurrence of this deformation only in northwestern Europe, as well as its timing and the direction of deformation, are congruent with inversions related to the North Atlantic opening.

The uppermost Ypresian deformation is again a West European-scale deformation (Fig. 10a). In the Aquitaine Basin, it corresponds to a major hiatus on the northern Aquitaine platform (Sztrakos et al., 2010), and the development of a flexural basin in the eastern Aquitaine Basin (Corbières, Christophoul et al., 2003). On the southwestern border of the North Sea (Belgium), the main deformation occurred during the uppermost Ypresian (Vandenberghe et al., 1998, 2004), with an uplift of the southern part of the Brabant and the erosion of the incised valleys of the Bruxelles Sands Fm. In the Wessex-Hampshire basins, the overall progradation of the London Clays Fm (King, 1981) is disrupted by a tectonic-induced unconformity (Newell, 2014) within the base of the Brackelsham Gp. This deformation is currently reported for the Africa-Eurasia convergence (Pyrenean compression). The timing and axis of the observed deformation are congruent with such a compressional deformation.

\subsection{Control of inherited Variscan structures on Palaeogene deformations}

Our study demonstrates a reactivation of crustal Variscan faults but with limited play, except for Sparnacian time (Cycle Cy1). Fault reactivation does not significantly affect the palaeogeography and thickness distribution. During longwavelength deformations, crustal fault reactivation is not significant, but these deformations involve a larger thickness of the lithosphere.

In contrast, during Sparnacian times, Seine, Valpuiseaux, and Rambouillet faults are bounding the Hurepoix Block which is strongly reactivated. Sparnacian time is also the period during which maximum accommodation variations are measured over Bray and Belou faults. Interestingly, Sparnacian deformations are of smaller (medium) wavelength, affecting a thinner part of the lithosphere and related to a different geodynamic event.

During Thanetian (Ct cycle) and Ypresian (Cy2 cycle) times, depocentres were located north of the Bray Fault or on both sides of the same Bray Fault (Fig. 1). This subsiding domain is limited toward the SE by the St Martin-de-Bossenay Fault (Fig. 1). Maximum subsidence areas are located along the Belou Fault.

This domain corresponds to the location of the remnant Variscan subducted slab (Averbuch and Piromallo, 2012), which could be the control of the long-term subsidence of the Paris Basin, rather than a Permo-Triassic extension that does not exist in this area (Delmas et al., 2002).

\section{Conclusions}

The objective of this study was to use high-resolution 3-D stratigraphic data to discuss the deformation of an intracratonic basin, the Paris Basin, at the time of a major change in subsidence occurring around the Cretaceous-Palaeogene boundary, from the subsiding Cretaceous time to a (very) low subsiding Palaeogene time with low sediment preservation.

- An age model integrating biostratigraphic uncertainties, sequence stratigraphic surfaces, high-resolution oxygen isotope curves (Cramer et al., 2011), and Earth orbital solutions for long-term eccentricity (Laskar et al., 2011) was performed at a resolution of $100 \mathrm{Kyrs}$ (Fig. 3 and Table 2).

- A 3-D stratigraphic database comprising more than 300 well-logs and eight time lines (depth, lithology facies) was built (Figs. 6, 7, 8, and 9).

- A 2-D accommodation space measurement was performed along a significant $\mathrm{S}-\mathrm{N}$ transect to constrain the nature of the deformation (Fig. 5).

- Two orders of sequences were identified: from 400 to $800 \mathrm{Kyrs}$ and from 1 to $5 \mathrm{Ma}$. The first one is assumed to be controlled by eustasy and the second one by tectonic (Ct, Thanetian; Cy2, Ypresian) or enhanced by sedimentary flux (climatic ?; Cy1, Ypresian).

- The tectonic control is due to flexures initiated north of the Bray Fault and progressively decreasing with spatial homogenization of the subsidence.

- Three phases of deformation were recognized:

a. Intra-Maastrichtian-pre-Thanetian (T1, 59 Ma) major long-wavelength deformations with formation of the present-day ring shape of the Paris Basin, its emersion and the major change in the sedimentary systems from open marine chalk to siliciclastic shore deposits (Fig. 10b). This European-scale deformation corresponds to the Laramide deformation (Ziegler, 1990) and is coeval with Upper Cretaceous pre-Danian compressive deformations linked to the Africa-Eurasia convergence, which is well recorded in southern France (Pyreneo-Provençal deformations) and with the paroxysm of a large volcanic province extending from the North Atlantic to the French Massif Central and the Rhenish Shield during the Palaeocene (Fig. 10a). Two stages of deformation - poorly dated - occurred during the uppermost Maastrichtian to pre-Thanetian.

b. Early Ypresian (T4-Y2, 56.4-54.3 Ma) minor medium-wavelength deformation with an inversion of one of the Variscan units in the Paris Basin - the 
Hurepoix Block. This might be due to lithospheric stress relaxation, and could be correlated with stress rearrangement related to the onset of the North Atlantic opening (Fig. 10a).

c. Uppermost Ypresian (intra NP 13 - mean 49.8 Ma) uplift of the Paris Basin at a long wavelength $(\times 100 \mathrm{~km})$ corresponding to the emersion of the whole basin. This deformation is recorded in the Aquitaine Basin and is also significant in the southern North Sea and in the Hampshire Basin, where it probably records an uplift of the Brabant-Midland Caledonian Block. This deformation is contemporaneous with flexural compressive deformations in southern France, related to the Iberia-Eurasia convergence (Fig. 10a).

This detailed stratigraphic study provides evidence for the subtle response of the European lithosphere to rearrangements of the plate tectonics. This type of stratigraphic study provides strong constraints to document long-wavelength deformation in a Palaeozoic continental lithosphere.

\section{The Supplement related to this article is available online at doi:10.5194/se-7-205-2016-supplement.}

Acknowledgements. We are grateful to the BRGM (Bureau de Recherches Géologiques et Minières) for funding the Justine Briais Ph.D. thesis. We thank Chantal Bourdillon (ERADATA) for biostratigraphic dating and Olivier Dauteuil for its help. We also thank Sara Mullin for the English translation. Finally, we thank the editor P. Galy, and Jocelyn Barbarand and an anonymous reviewer for their constructive comments.

Edited by: P. Albert Galy

\section{References}

Allen, J. R.: Sand waves: A model of origin and internal structure, Sediment. Geol., 26, 281-328, 1980.

Allen, J. R.: Sedimentary structures, their character and physical basis, Elsevier, 1982.

Allen, P. A. and Homewood, P.: Evolution and mechanics of a Miocene tidal sandwave, Sedimentology, 31, 63-81, 1984.

Amorosi, A.: Detecting compositional, spatial, and temporal attributes of glaucony: a tool for provenance research, Sediment. Geol., 109, 135-153, 1997.

André, G., Hibsch, C., Fourcade, S., Cathelineau., M., and Buschaert, S.: Chronology of fracture sealing under a meteoric fluid environment: Microtectonic and isotopic evidence of major Cainozoic events in the eastern Paris Basin (France), Tectonophysics, 490, 214-228, 2010.
Anell, I., Thybo, H., and Artemieva, I. M.: Cenozoic uplift and subsidence in the North Atlantic region: Geological evidence revisited, Tectonophysics, 474, 78-105, 2009.

Arnott, R. W. and Southard, J. B.: Exploratory flow-duct experiments on combined-flow bed configurations, and some implications for interpreting storm-event stratification, J. Sediment. Res., 60, 211-219, 1990.

Aubry, M. P.: Biostratigraphie du Paléogène épicontinental de l'Europe du Nord-Ouest: étude fondée sur les nannofossiles calcaires, Ph.D. Thesis, Université Claude Bernard, Lyon, France, 317 pp., 1983.

Aubry, M. P.: Paleogene calcareous nannoplankton biostratigraphy of northwestern Europe, Palaeogeogr. Palaeocl., 55, 267-334, 1986.

Aubry, M. P., Thiry, M., Dupuis, C., and Berggren, W. A.: The Sparnacian deposits of the Paris Basin: Part I., A lithostratigraphic classification, Stratigraphy, 2, 65-100, 2005.

Autran, A., Castaing, C., Debeglia, N., Guillen, A., and Weber, C.: Nouvelles contraintes géophysiques et géodynamiques pour l'interprétation de l'anomalie magnétique du bassin de Paris; hypothèse d'un rift paléozoïque referme au Carbonifère, B. Soc. Geol. Fr., 2, 125-141, 1986.

Autran, A., Lefort, J. P., Debeglia, N., Edel, J. B., and Vigneresse, J. L.: Gravity and Magnetic Expression of Terranes in France and Their Correlation Beneath Overstep Sequences, in: Pre-Mesozoic Geology in France and Related Areas, edited by: Chantraine, J., Rolet, J., Santallier, D. S., Piqué, A., and Keppie, J. D., IGCP-Project 233, Springer Berlin Heidelberg, 49-72, 1994.

Averbuch, O. and Piromallo, C.: Is there a remnant Variscan subducted slab in the mantle beneath the Paris basin? Implications for the late Variscan lithospheric delamination process and the Paris basin formation, Tectonophysics, 558, 70-83, 2012.

Baranyi, I., Lippolt, H. J., and Todt, W.: KaliumArgon-Altersbestimmungen an tertiären Vulkaniten des Oberrheingraben-Gebietes: II Die Alterstraverse vom Hegau nach Lothringen, Oberrhein. Geol. Abh., 25, 41-62, 1976.

Barbarand, J., Quesnel, F., and Pagel, M.: Lower Paleogene denudation of Upper Cretaceous cover of the Morvan Massif and southeastern Paris Basin (France) revealed by AFT thermochronology and constrained by stratigraphy and paleosurfaces, Tectonophysics, 608, 1310-1327, 2013.

Beccaletto, L., Hanot, F., Serrano, O., and Marc, S.: Overview of the subsurface structural pattern of the Paris Basin (France): Insights from the reprocessing and interpretation of regional seismic lines, Mar. Petrol. Geol., 28, 861-879, 2011.

Bellon, H., Gillot, P., and Nativel, P.: Eocene volcanic activity in Bourgogne, Charollais, Massif Central (France), Earth Planet. Sc. Lett., 23, 53-58, 1974.

Bertrand, M. A.: Sur la continuité du phénomène de plissement dans le bassin de Paris, Imp. Le Bigot Frères, 1892.

Bignot, G.: The position of the Montian Stage and related facies within the stratigraphic-palaeogeographic framework of NW Europe during the Danian, Contributions to Tertiary and Quaternary Geology, 29, 47-59, 1993.

Bignot, G. and Neuman, M.: Les "grands" foraminifères du Crétacé terminal et du Paléogène du Nord-Ouest européen; recensement et extensions chronologiques, Bull. Inf. Geo. Bass. Paris, 28, 1329, 1991. 
Bignot, G., Janin, M.-C., and Guernet, C.: Mise en évidence de la zone de nannofossiles calcaires NP9 dans le Thanétien de Rollot (Bassin de Paris), Bull. Inf. Geo. Bass. Paris, 31, 25-28, 1994.

Blanc, P. and Guillevin, Y.: Nouvel indice de Maestrichtien dans l'Est du Bassin de Paris, C. R. Acad. Sc. Paris, 273, 465-467, 1974.

Blanc-Valleron, M. M. and Thiry, M.: Minéraux argileux, paléoaltérations, paléopaysages et séquence climatique : exemple du Paléogène continental de France, in: Sédimentologie et Géochimie de la Surface, edited by: Paquet, H. and Clauer, N., Colloque à la mémoire de Georges Millot. Collection de l'Académie des Sciences et CADAS, 199-216, 1993.

Blès, J.-L., Bonijoly, D., Castaing, C., and Gros, Y.: Successive post-Variscan stress fields in the French Massif Central and its borders (Western European plate): comparison with geodynamic data, Tectonophysics, 169, 79-111, 1989.

Blondeau, A.: Le Lutétien des Bassins de Paris, de Belgique et du Hampshire: étude sédimentologique et paléontologique, Ph.D. Thesis, Université de Paris, Faculté des Sciences, Paris, France, 469 pp., 1965.

Bolin, C., Tourenq, J., and Ambroise, D.: Sédimentologie et microfossiles pyritisés du sondage de Cuise-la-Motte (Bassin de Paris), Bull. Inf. Geo. Bass. Paris, 19, 55-65, 1982.

Boulila, S., Galbrun, B., Miller, K. G., Pekar, S. F., Browning, J. V., Laskar, J., and Wright, J. D.: On the origin of Cenozoic and Mesozoic "third-order" eustatic sequences, Earth Sci. Reviews, 109, 94-112, 2011.

Briais, J.: Le Cénozoïque du bassin de Paris: un enregistrement sédimentaire haute resolution des deformations lithosphériques en régime de faible subsidence, Ph.D., Université de Rennes 1, Rennes, 466 pp., 2015.

Briais, J., Guillocheau, F., Lasseur, E., Robin, C., Chateauneuf, J.J., Dauteuil., O., and Serrano, O.: Response of sedimentary systems to lithospheric flexure: the Palaeogene period of the Paris Basin, Sediment. Geol., in prep, 2016.

Brunet, M. F. and Le Pichon, X.: Subsidence of the Paris Basin, J. Geophys. Res., 87, 8547-8560, 1982.

Catuneanu, O., Abreu, V., Bhattacharya, J. P., Blum, M. D., Dalrymple, R. W., Eriksson, P. G., Fielding, C. R., Fisher, W. L., Galloway, W. E., Gibling, M. R., Giles, K. A., Holbrook, J. M., Jordan, R., Kendall, C. G. S. C., Macurda, B., Martinsen, O. J., Miall, A. D., Neal, J. E., Nummedal, D., Pomar, L., Posamentier, H. W., Pratt, B. R., Sarg, J. F., Shanley, K. W., Steel, R. J., Strasser, A., Tucker, M. E., and Winker, C.: Towards the standardization of sequence stratigraphy, Earth Sci. Rev., 92, 1-33, 2009.

Chateauneuf, J. J. and Gruas-Cavagnetto, C.: Les zones de Wetzeliellaceae (Dinophyceae) du Bassin de Paris; comparaison et corrélations avec les zones du Paléogène des bassins du NordOuest de l'Europe, Bull. Bureau de Recherches Géologiques et Minières, Section 4: Géologie Générale, 2, 59-93, 1978.

Christophoul, F., Soula, J. C., Brusset, S., Elibana, B., Roddaz, M., Bessiere, G., and Deramond, J.: Time, place and mode of propagation of foreland basin systems are recorded by the sedimentary fill; examples of the Late Cretaceous and Eocene retro-foreland basins of the north-eastern Pyrenees, Geol. Soc. London Spec. Pub., 208, 229-252, 2003.
Clifton, H. E., Hunter, R. E., and Phillips, R. L.: Depositional structures and processes in the non-barred high-energy nearshore, J. Sediment. Res., 41, 651-670, 1971.

Cloetingh, S. and Van Wees, J. D.: Strength reversal in Europe's intraplate lithosphere: Transition from basin inversion to lithospheric folding, Geology, 33, 285-288, 2005.

Cramer, B. S., Toggweiler, J., Wright, J., Katz, M., and Miller, K.: Ocean overturning since the Late Cretaceous: Inferences from a new benthic foraminiferal isotope compilation, Paleoceanography, 24, PA4216, doi:10.1029/2008PA001683, 2009.

Cramer, B. S., Miller, K. G., Barrett, P. J., and Wright, J. D.: Late Cretaceous-Neogene trends in deep ocean temperature and continental ice volume; reconciling records of benthic foraminiferal geochemistry (delta $\left(\delta \mathrm{O}^{18}\right.$ and $\mathrm{Mg} / \mathrm{Ca}$ ) with sea level history, J. Geophys. Res., 116, C12, doi:10.1029/2011JC007255, 2011.

Cross, T. A.: Controls on coal distribution in transgressive regressive cycles, Upper Cretaceous, Western Interior, USA, in: Sea level changes, an integrated approach, edited by: Wilgus, C., Hastings, B. S., Kendall, C. G. S. C., Posamentier, H. W., Ross, C. A., and Van Wagoner, J. C., Soc. Econ. Paleont. Mineral., Spec. Publi., 42, 371-380, 1988.

Cross, T. A. and Lessenger, M. A.: Sediment volume partitioning: rationale for stratigraphic model evaluation and high-resolution stratigraphic correlation, Sequence Stratigraphy-Concepts and Application, Norwegian Petroleum Society Special Publication, 8, 171-195, 1998

Dabrio, C. J.: Sedimentary structures generated on the foreshore by migrating ridge and runnel systems on microtidal and mesotidal coasts of S. Spain, Sediment. Geol., 32, 141-151, 1982.

Dalrymple, R. W. and Choi, K.: Morphologic and facies trends through the fluvial-marine transition in tide-dominated depositional systems: a schematic framework for environmental and sequence-stratigraphic interpretation, Earth Sci. Rev., 81, 135174, 2007.

Dauteuil, O., Robin, C., Guillocheau, F., Linol, B., Calvès, G., and Moreau, F.: Basin subsidence quantification: impacts of backstripping parameters and geological inputs, Terra Nova, in prep., 2016.

Davis, Jr., R. A., Fox, W. T., Hayes, M. O., and Boothroyd, J. C.: Comparison of ridge and runnel systems in tidal and non-tidal environments, J. Sediment. Res., 42, 413-421, 1972.

Deckers, J., Broothaers, M., Lagrou, D., and Matthijs, J.: The late Maastrichtian to Late Paleocene tectonic evolution of the Southern part of the Roer Valley Graben (Belgium), Neth. J. Geosci., 93, 83-93, 2014.

Delmas, J., Houel, P., and Vially, R.: Paris Basin, Petroleum potential, IFP regional report, Paris, 2002.

Doré, A., Lundin, E., Jensen, L. N., Birkeland, Ø., Eliassen, P. E., and Fichler, C.: Principal tectonic events in the evolution of the northwest European Atlantic margin, Geol. Soc. London, Petroleum Geology Conference, Series, 5, 41-61, 1999.

Dumas, S., Arnott, R. W. C., and Southard, J. B.: Experiments on oscillatory-flow and combined-flow bed forms: implications for interpreting parts of the shallow-marine sedimentary record, J. Sediment. Res., 75, 501-513, 2005.

Dutheil, D. B., Moreau, F., and Delhaye-Prat, V.: Cycle sédimentaire et vertèbres d'une formation peu connue du bassin de Paris, l'unité des sables de Bourguillemont (Oise, France) (Paléocène supérieur), Geodiversitas, 24, 753-764, 2002. 
Elliott, T.: Deltas, in: Sedimentary environments and facies, Blackwell Scientific Publications, Oxford, 2, 113-154, 1986.

Embry, A.: Practical sequence stratigraphy, CSPG, 81 pp., 2009.

Feugueur, L.: L'Yprésien du Bassin de Paris: essai de monographie stratigraphique, Imprimerie Nationale, 1963.

Gale, A. S., Jeffery, P., Huggett, J., and Connolly, P.: Eocene inversion history of the Sandown Pericline, Isle of Wight, southern England, J. Geol. Soc., 156, 327-339, 1999.

Galloway, W. E.: Genetic stratigraphic sequences in basin analysis II: application to northwest Gulf of Mexico Cenozoic basin, AAPG Bull., 73, 143-154, 1989.

Gradstein, F. M., Ogg, G., and Schmitz, M.: The Geologic Time Scale 2012, 2-Volume Set, Elsevier, 2012.

Greenwood, B. and Sherman, D. J.: Hummocky cross-stratification in the surf zone: flow parameters and bedding genesis, Sedimentology, 33, 33-45, 1986.

Gruas-Cavagnetto, C.: Etude palynologique du sondage de Cuisela-Motte (Oise), Bull. Inf. Geol. Bass. Paris, 13, 11-23, 1976.

Guettard, J.: Mémoire et carte minéralogique sur la nature et la situation des terrains qui traversent la France et l'Angleterre, Mémoire de l'Académie Royale des Sciences, 363-393, 1746.

Guillocheau, F.: Mise en évidence de grands cycles transgressionrégression d'origine tectonique dans les sédiments mésozoïques du Bassin de Paris, CR Acad. Sci. II, 312, 1587-1593, 1991.

Guillocheau, F., Robin, C., Allemand, P., Bourquin, S., Brault, N., Dromart, G., Friedenberg, R., Garcia, J. P., Gaulier, J. M., Gaumet, F., Grosdoy, B., Hanot, F., Le Strat, P., Mettraux, M., Nalpas, T., Prijac, C., Rigollet, C., Serrano, O., and Grandjean, G.: Meso-Cenozoic geodynamic evolution of the Paris Basin; 3D stratigraphic constraints, Geodin. Acta, 13, 189-245, 2000.

Hampson, G. J. and Storms, J. E.: Geomorphological and sequence stratigraphic variability in wave-dominated, shorefaceshelf parasequences, Sedimentology, 50, 667-701, 2003.

Haq, B. U., Hardenbol, J., and Vail, P. R.: Chronology of fluctuating sea levels since the Triassic, Science, 235, 1156-1167, 1987.

Harms, J.: Stratification and sequence in prograding shoreline deposits, SEPM, Spec. P., 1975.

Homewood, P., Guillocheau, F., Eschard, R., and Cross, T. A.: Corrélations haute résolution et stratigraphie génétique; une démarche intégrée, Bull. Centres Rech. Explor. Prod. ElfAquitaine, 16, 357-381, 1992.

Howard, J. D. and Reineck, H.-E.: Depositional facies of highenergy beach-to-offshore sequence: comparison with low-energy sequence, AAPG Bull., 65, 807-830, 1981.

Hunter, R. E., Clifton, H. E., and Phillips, R. L.: Depositional processes, sedimentary structures, and predicted vertical sequences in barred nearshore systems, southern Oregon coast, J. Sediment. Res., 49, 1979.

Jacobs, P. and De Batist, M.: Sequence stratigraphy and architecture on a ramp-type continental shelf: the Belgian Palaeogene, J. Geol. Soc. London, Sp. Pub., 117, 23-48, 1996.

Janin, M. C. and Bignot, G.: Nouvelle subdivision biostratigraphique du Thanétien du Bassin de Paris, fondée sur les nannofossiles calcaires, CR Acad. Sci. II, 317, 927-934, 1993.

Jervey, M. T.: Quantitative geological modeling of siliciclastic rock sequences and their seismic expression, Soc Econ. Pa., 42, 4769, 1988.
Kidwell, S. M., Fuersich, F. T., and Aigner, T.: Conceptual framework for the analysis and classification of fossil concentrations, Palaios, 1, 228-238, doi:10.2307/3514687, 1986.

King, C.: The Stratigraphy of the London Clay and associated deposits, Tertiary Research, Sp. Pub., 6, 1981.

Knox, R. W. O. B.: Tectonic controls on sequence development in the Palaeocene and earliest Eocene of southeast England: implications for North Sea stratigraphy, J. Geol. Soc. London, Sp. Pub., 103, 209-230, 1996.

Köthe A.: Dinozysten-Zonierung im Tertiär Norddeutschlands, Revue de Paléobiologie, 22, 895-923, 2003.

Köthe, A.: A revised Cenozoic dinoflagellate cyst and calcareous nannoplankton zonation for the German sector of the southeastern North Sea Basin, Newsl. Stratigr., 45, 189-220, 2012.

Lamarche, J., Scheck, M., and Lewerenz, B.: Heterogeneous tectonic inversion of the Mid-Polish Trough related to crustal architecture, sedimentary patterns and structural inheritance, Tectonophysics, 373, 75-92, doi:10.1016/S00401951(03)00285-3, 2003.

Laskar, J., Fienga, A., Gastineau, M., and Manche, H.: La2010: A new orbital solution for the long term motion of the Earth, Astron. Astrophys., 428, 261-285, 2011.

Laurain, M. and Meyer, R.: Stratigraphie et paléogéographie du Paléogène champenois, Géologie de la France, 1, 103-123, 1986.

Le Roy, P., Gracia-Garay, C., Guennoc, P., Bourillet, J. F., Reynaud, J. Y., Thinon, I., Kervevan, P., Paquet, F., Menier, D., and Bulois, C.: Cenozoic tectonics of the Western Approaches Channel basins and its control of local drainage systems, B. Soc. Geol. Fr., 182, 451-463, 2011.

Leckie, D. A. and Walker, R. G.: Storm-and tide-dominated shorelines in Cretaceous Moosebar-Lower Gates interval-outcrop equivalents of Deep Basin gas trap in western Canada, AAPG Bull., 66, 138-157, 1982.

Leleu, S.: Les cônes alluviaux Crétacé supérieur/Paléocène en Provence: traceurs de l'évolution morpho-tectonique des stades précoces de collision, Ph.D. Thesis, Université Louis Pasteur, Strasbourg, France, 222 pp., 2005.

Lemoine, P.: Géologie du bassin de Paris, A. Hermann et Fils, 1911.

Lenoir, X., Dautria, J.-M., Briqueu, L., Cantagrel, J. M., and Michard, A.: Nouvelles données géochronologiques, géochimiques et isotopiques sur le volcanisme du Forez: relation avec l'évolution cénozoïque du manteau du Massif central, CR Acad. Sci. IIA, 330, 201-207, 2000.

Mascle, A.: Géologie pétrolière des bassins permiens français; Comparaison avec les bassins permiens du Nord de l'Europe, Chron. Rech. Min, 499, 69-86, 1990.

Matte, P.: Tectonics and plate tectonics model for the Variscan belt of Europe, Tectonophysics, 126, 329-374, doi:10.1016/00401951(86)90237-4, 1986.

Mégnien, C. and Mégnien, F.: Synthèse géologique du Bassin de Paris, In: Geological synthesis of the Paris Basin; Volume I, Stratigraphy and paleogeography, Bureau de Recherches Géologiques et Minières, (BRGM), Paris, France, 1980.

Mégnien, C. and Hanot, F. (Eds.): Programme Craie 700: deux forages scientifiques profonds pour étudier les phénomènes diagénétiques de grande ampleur dans la craie du Bassin de Paris, Bull. Inf. Geol. Bass. Paris, 37, 3-147, 2000.

Miller, K. G., Kominz, M. A., Browning, J. V., Wright, J. D., Mountain, G. S., Katz, M. E., Sugarman, P. J., Cramer, B. S., Christie- 
Blick, N., and Pekar, S. F.: The Phanerozoic record of global sea-level change, Science, 310, 1293-1298, 2005.

Montenat, C., Barrier, P., and D'Estevou, P. O.: The Vigny limestones: a record of Palaeocene (Danian) tectonic-sedimentary events in the Paris Basin, Sedimentology, 49, 421-440, 2002.

Müller, R. D., Sdrolias, M., Gaina, C., Steinberger, B., and Heine, C.: Long-Term Sea-Level Fluctuations Driven by Ocean Basin Dynamics, Science, 319, 1357-1362, 2008.

Mussett, A., Dagley, P., and Skelhorn, R.: Time and duration of activity in the British Tertiary Igneous Province, Geol. Soc. London, Sp. Pub., 39, 337-348, 1988.

Mutti, E., Roseli, J., Allen, G., Fonnesu, F., and Sgavetti, M.: In The Eocene Baronia tide dominated delta-shelf system in the Ager Basin: International Association of Sedimentologists 6th European Regional Meeting, Excursion Guidebook, 579-600, 1985.

Nel, A., de Plöeg, G., Dejax, J., Dutheil, D., de Franceschi, D., Gheerbrant, E., Godinot, M., Hervet, S., Menier, J. J., and Augé, M.: Un gisement sparnacien exceptionnel à plantes, arthropodes et vertébrés (Éocène basal, MP7): Le Quesnoy (Oise, France), CR Acad. Sci. IIA, 329, 65-72, 1999.

Newell, A. J.: Construction of a Palaeogene tide-dominated shelf: influence of Top Chalk topography and sediment supply (Wessex Basin, UK), J. Geol. Soc., 158, 379-390, 2001.

Newell, A. J.: Palaeogene rivers of southern Britain: climatic extremes, marine influence and compressional tectonics on the southern margin of the North Sea Basin, P. Geologist. Assoc., 125, 578-590, 2014.

Nio, S. and Yang, C.: Sea-level fluctuations and the geometric variability of tide-dominated sandbodies, Sediment. Geol., 70, 161193, 1991.

Perrodon, A. and Zabek, J.: Paris Basin, in: Interior cratonic basins, edited by: Leighton, M. W., Kolata, D. R., Oltz, D. F., and Eidel, J. J., AAPG Memoir, 633-679, 1990.

Platel, J. P.: Stratigraphie, sédimentologie et évolution géodynamique de la plate-forme carbonatée du Crétacé supérieure du nord du bassin d'Aquitaine, Géologie de la France, 4, 33-58, 1996.

Plaziat, J. C.: Late Cretaceous to Late Eocene palaeogeographic evolution of southwest Europe, Palaeogeogr. Palaeocl., 36, 263320, 1981.

Pomerol, B. and Riveline, J.: Etude floristique (Characée) des calcaires de Mortemer et de Cuvilly dans leurs localités-types, CR Acad. Sci. D. NAT., 280, 2725-2728, 1975.

Pomerol, B., Renard, M., and Riveline, J.: Données nouvelles sur le Thanétien supérieur du Nord du Bassin de Paris; La limite Paléocène-Eocène dans les bassins nordiques et sa corrélation avec les bassins mesogéens, B. Soc. Geol. Fr., 7, 155-164, 1977.

Pomerol, C.: Stratigraphy of the Palaeogene; hiatuses and transitions, P. Geologist. Assoc., 100, 313-324, 1989.

Postma, G.: Depositional architecture and facies of river and fan deltas: a synthesis, Coarse-grained deltas, Spec. Publs int. Ass. Sediment., 10, 13-27, 1990.

Quesnel, F.: Paleoweathering and paleosurfaces from northern and eastern France to Belgium and Luxembourg: geometry, dating and geodynamic implications, Géologie de la France, 1, 95-104, 2003.

Quesnel, F., Bourdillon, C., and Laignel, B.: Maastrichtien supérieur au Nord-Ouest du Bassin de Paris (France), Témoins résiduels en Seine-Maritime, CR Acad. Sc. Paris, 322, 10711077, 1996.

Quesnel, F., Storme, J. Y., Iakovleva, A. I., Roche, E., Breillat, N., André, M., and Dupuis, C.: Unravelling the PETM record in the "Sparnacian" of NW Europe: new data from Sinceny, Paris Basin, France, in: CEBP, Austria, 6 June 2011, 2011.

Raymo, M. E., Mitrovica, J. X., O'Leary, M. J., DeConto, R. M., and Hearty, P. J.: Departures from eustasy in Pliocene sea-level records, Nat. Geosci., 4, 328-332, 2011.

Reineck, H. E. and Wunderlich, F.: Classification and origin of flaser and lenticular bedding, Sedimentology, 11, 99-104, 1968.

Reischmann, T., Beiträgen, M., von Nesbor, H. D., and Wimmenauer, W.: 1.3 Tertiärer Vulkanismus, in: Deutsche Stratigraphische Kommission (ed) Stratigraphie von Deutschland IX, Tertiär, Teil 1., Oberrheingraben und benachbarte Tertiärgebiete, Schriftenr. Dt. Ges. Geowiss., 75, 16-30, 2011.

Reading, H. G. and Collinson, J. D.: Clastic coasts, in, Reading, HG ed., Sedimentary Environments, Processes, Facies and Stratigraphy, Blackwell Science, 154-231, 1996.

Riveline, J.: Les Charophytes du Cénozoïque (Danien à Burdigalien) d'Europe occidentale, Implications stratigraphiques, Ph.D. Thesis, Mémoire des Sciences de la Terre, Université Pierre et Marie Curie, Paris, France, 523 pp., 1984.

Roberts, D., Thompson, M., Mitchener, B., Hossack, J., Carmichael, S., and Bjørnseth, H. M.: Palaeozoic to Tertiary rift and basin dynamics: mid-Norway to the Bay of Biscay-a new context for hydrocarbon prospectivity in the deep water frontier, J. Geol. Soc. London, Petroleum Geology Conference Series, 5, 7-40, 1999.

Robin, C., Guillocheau, F., and Gaulier, J. M.: Discriminating between tectonic and eustatic controls on the stratigraphic record in the Paris basin, Terre Nova, 10, 323-329, 1998.

Rocher, M., Cushing, M., Lemeille, F., Lozac'h, Y., and Angelier, J.: Intraplate paleostresses reconstructed with calcite twinning and faulting: improved method and application to the eastern Paris Basin (Lorraine, France), Tectonophysics, 387, 1-21, 2004.

Rosenbaum, G., Lister, G. S., and Duboz, C.: Relative motions of Africa, Iberia and Europe during Alpine Orogeny, Tectonophysics, 359, 117-129, 2002.

Rowley, D. B.: Sea Level: Earth's Dominant Elevation - Implications for Duration and Magnitudes of Sea Level Variations, J. Geol., 121, 445-454, 2013.

Rudge, J. F., Shaw Champion, M. E., White, N., McKenzie, D., and Lovell, B.: A plume model of transient diachronous uplift at the Earth's surface, Earth. Planet. Sc. Lett., 267, 146-160, 2008.

Russell, D. E.: Les mammifères paléocènes d'Europe, Editions du Muséum, 1964.

Schlager, W.: Accommodation and supply - a dual control on stratigraphic sequences, Sediment. Geol., 86, 111-136, 1993.

Schmitt, A. K., Marks, M. A., Nesbor, H. D., and Markl, G.: The onset and origin of differentiated Rhine Graben volcanism based on $\mathrm{U}-\mathrm{Pb}$ ages and oxygen isotopic composition of zircon, Eur. J. Mineral., 19, 849-857, 2007.

Serrano, O.: Le Crétacé supérieur/Paléogène du bassin compressif nord-pyrénéen (bassin de l'Adour) Sédimentologie, stratigraphie, géodynamique, Ph.D. Thesis, Les Mémoires de Géosciences Rennes, Université de Rennes 1, Rennes, France, 173 pp., 2001. 
Smith, T., Quesnel, F., De Plöeg, G., De Franceschi, D., Métais, G., De Bast, E., Solé, F., Folie, A., Boura, A., and Claude, J.: First Clarkforkian Equivalent Land Mammal Age in the Latest Paleocene Basal Sparnacian Facies of Europe: Fauna, Flora, Paleoenvironment and (Bio) stratigraphy, PLos One, 9, 3, doi:10.1371/journal.pone.0086229, 2014.

Steurbaut, E.: High-resolution holostratigraphy of Middle Paleocene to Early Eocene stratain Belgium and adjacent areas, Palaeontogr. Abt. A., 247, 91-156, 1998.

Strasser, A., Hillgärtner, H., Hug, W., and Pittet, B.: Third-order depositional sequences reflecting Milankovitch cyclicity, Terra Nova, 12, 303-311, 2000.

Sztrákos, K., Blondeau, A., and Hottinger, L.: Lithostratigraphie et biostratigraphie des formations marines paléocènes et éocènes nord-aquitaines (bassins de Contis et Parentis, seuil et plate-forme nord-aquitains), Foraminifères éocènes du bassin d'Aquitaine, Géologie de la France, 2, 3-52, 2010.

Thiry, M.: Sédimentation continentale et altérations associées; calcitisations, ferruginisations et silicifications; les argiles plastiques du Sparnacien du Bassin de Paris, Ph.D. Thesis, Mémoires des Sciences Géologiques, Université Louis Pasteur, Strasbourg, France, 173 pp., 1981.

Thiry, M.: Geochemical evolution and paleoenvironments of the Eocene continental deposits in the Paris Basin, Palaeogeogr. Palaeocl., 70, 153-163, 1989.

Van Wagoner, J. C., Posamentier, H. W., Mitchum, R. M., Vail, P. R., Sarg, J. F., Loutit, T. S., and Hardenbol, J.: An overview of the fundamentals of sequence stratigraphy and key definitions, in: C. Wilgus et al. Eds., Sea level changes, an integrated approach., Soc. Econ. Paleont. Mineral. Spec. Publi., 42, 39-45, 1988.

Van Wagoner, J. C., Mitchum, R., Campion, K., and Rahmanian, V.: Siliciclastic sequence stratigraphy in well logs, cores, and outcrops: concepts for high-resolution correlation of time and facies, AAPG Methods in exploration Series, 7, 1990.

Vandenberghe, N., Laga, P., Steurbaut, E., Hardenbol, J., and Vail, P.R.: Tertiary sequence stratigraphy at the southern border of the North Sea Basin in Belgium, SEPM, Sp. Publ., 60, 119-154, 1998.

Vandenberghe, N., Van Simaeys, S., Steurbaut, E., Jagt, J., and Felder, P.: Stratigraphic architecture of the Upper Cretaceous and Cenozoic along the southern border of the North Sea Basin in Belgium, Neth. J. Geosci., 83, 155-171, 2004.
Vandycke, S.: Palaeostress records in Cretaceous formations in NW Europe: extensional and strike-slip events in relationships with Cretaceous-Tertiary inversion tectonics, Tectonophysics, 357, 119-136, 2002.

Vandycke, S. and Bergerat, F.: Brittle tectonic structures and palaeostress analysis in the Isle of Wight, Wessex basin, southern UK, J. Struct. Geol., 23, 393-406, 2001.

Vandycke, S., Bergerat, F., and Dupuis, C.: Paléo-contraintes à la limite Crétacé-Tertiaire dans le bassin de Mons (Belgique). Implications cinématiques. Relations avec la Zone de Cisaillement Nord-Artois, CR Acad. Sci. II, 307, 303-309, 1989.

Vincent, P., Aubert, M., Boivin, P., Cantagrel, J., and Lenat, J.: Découverte d'un volcanisme paléocène en Auvergne; les maars de Menat et leurs annexes, étude géologique et géophysique, B. Soc. Geol. Fr., 5, 1057-1070, 1977.

Visser, M.: Neap-spring cycles reflected in Holocene subtidal largescale bedform deposits: a preliminary note, Geology, 8, 543-546, 1980.

Voisin, L.: Introduction à l'étude de la pierre de Stonne et des formations siliceuses associées au Sud-Ouest de l'Ardenne, Société d'histoire naturelle des Ardennes, 1988.

Walker, R. and Plint, A. G.: Wave- and storm-dominated shallow marine systems, in:Facies Model. Geological Association of Canada, edited by: Walker, R. G., James, N. P., St. Johns, NL, Canada, 219-238, 1992.

White, N. and Lovell, B.: Measuring the pulse of a plume with the sedimentary record, Nature, 387, 888-891, 1997.

Wright, L.: Sediment transport and deposition at river mouths: a synthesis, Geol. Soc. Am. Bull., 88, 857-868, 1977.

Wyns, R. and Ducreux, L.: L'Eocène inférieur de Brie et de Champagne (Bassin de Paris), Synthèse paléogéographique et stratigraphique, Bureau de Recherches Géologiques Minières (BRGM), Rapport 83-SGN-297-GEO, 154, 1983.

Ziegler, P. A.: Celtic Sea-Western Approaches area: an overview, Tectonophysics, 137, 285-289, 1987a.

Ziegler, P. A.: Evolution of the Western Approaches Trough, Tectonophysics, 137, 341-346, 1987b.

Ziegler, P. A.: Geological atlas of Western and Central Europe: Shell Internationale Petroleum Maatschappij BV, Geol. Soc. London, 1-239, 1990.

Ziegler, P. A.: European Cenozoic rift system, Tectonophysics, 208, 91-111, 1992. 